\title{
Can player economic value rights be used as collateral?
}

\author{
Matteo Maciel ${ }^{1,2} \cdot$ Adam Walton $^{2}$
}

Published online: 2 January 2019

(c) The Author(s) 2018

\begin{abstract}
As Association Football Clubs look to finance player transfer fees, lenders have seen an increasingly prevalent role and will seek to secure their loan against club assets. One of the methods of securing lending has been to utilise the transfer market value of player economic rights. This paper examines the insolvency effects of a lender taking an interest in the eventual, prospective proceeds of a sale of a player's economic rights. It asks how a transaction might be structured to secure a loan using the value of a player's economic right and examines the potential pitfalls within the private international law rules of association football and the insolvency rules of England and Wales. The authors suggest that FIFA regulations involving third-party participation, Articles 18bis and 18ter, are incongruent with the rules controlling the same matter as found within the English FA and the English Premier League. The result produces inconsistent certainty as to how a lender could structure a loan. It is suggested that the FIFA regulations apply with direct effect and any transaction should heed to the stricter interpretation found therein. Secondly, the case in the matter of Football Creditors highlights a red line for the risks of unsecured lending to football clubs. The paper proposes two methods for ensuring a transaction provides a lender with adequate protection against insolvency and the Football Creditor Rule and against the unclear FIFA regulations when a lender uses the proceeds from the sale of a player's economic right as collateral.
\end{abstract}

Keywords FIFA · Football · Financial collateral · Floating charge · Asset-backed security · Third-party ownership · Lending $\cdot$ Sport financing

\section{Introduction}

Sport, particularly association football has seen an increased expansion of external financing in the decades since the Bosman ruling. ${ }^{1}$ Extensive discussion in both academia and sport has resulted in increased scrutiny onto how clubs raise capital to pursue ostentatious successes and player salaries, particularly in football. ${ }^{2}$ Commercialisation of the 'beautiful game' has brought forth financial demands. ${ }^{3}$ Outside the world of sport, collateral for lending has been crucial to capital raising, particularly in risky ventures. Risk-related consequences relating to the collateralisation of lending is especially noteworthy when considering the regulatory and insolvency rules which normalise the act of taking collateral.

Within England and Wales, security is crucial for lending activities. One might put aside the question of whether

Matteo Maciel

Matteo.maciel@gmail.com

1 Kirkland \& Ellis (International) LLP, London, England, UK

2 Brasenose College, Radcliffe Square, Oxford OX14AJ, UK on-pitch results are worthy endeavours. The paper will also not seek to examine whether the commercialisation of sport is justified. Instead, in light of the means by which sport has often achieved on-pitch results (through lending), the focus will remain on an increasingly common mechanism used by Professional Football teams ('Clubs') ${ }^{4}$ to collateralise funds. The paper instead asks whether leveraging the value of

\footnotetext{
${ }^{1}$ Sam Boor, Matthew Green, Chris Hanson, Andy Shaffer, Alexander Thorpe, and Christopher Winn, 'Annual Review of Football Finance 2016' Deloitte UK Sports Business Group, https://www2. deloitte.com/content/dam/Deloitte/uk/Documents/sports-busin ess-group/deloitte-uk-annual-review-of-football-finance-2016.pdf (accessed 20th November 2018).

2 See Football Creditors Case [2012] Bus LR 1539.

${ }^{3}$ Some critics, suggest that this unchecked pursuit has exasperated the current disparity by allowing managers with little financial acumen to leverage and gamble finances, see Terri Byers, Trevor Slack and Milena Parent, Key Concepts In Sport Management (SAGE, 2012); Danish Institute for Sport Studies, 'Sports Organizations, Autonomy And Good Governance', 2013, http://dspace.mah.se/ dspace/bitstream/handle/2043/17866/AGGIS_Final_report.pdf?seque nce $=2 \&$ is Allowed=y\#page=133 (accessed 29 March 2018).

4 "Club Structures: A guide to club structures for National League System and other Football Clubs" Muckle LLP, 2015.
} 
players on the transfer market can be used as collateral from a private and commercial law perspective. The proposal is best exemplified in a fictionalised scenario: could a club like, say, Manchester United ('United'), use debt to finance the transfer of five players: Cristiano Ronaldo, Lionel Messi, Gianluigi Buffon, Kylian Mbappe, and Christian Benteke, whilst securing the debt obligations by using, among other things the club's collective player economic rights derivative of their employment contract? What type of outcome would this yield for the club, and more importantly for the financial lenders-particularly if the club were to subsequently collapse, be relegated, or enter insolvency? While this example does not enquire into the other complexities associated with player transfers (such as the influence of player's preferences for playing at certain places), it does bring forth several substantive and procedural questions in view of the vital role collateral provides to lending, the cost of capital, and regulation. That is to say, as lenders look to extract higher levels of collateral, might they securitise the collective expected revenue (as differentiated from the individual dividends of specific players) of a club's entire player contracts? What are the associated (perhaps hidden) costs of such an endeavour? With agreements of this nature increasingly becoming prevalent, ${ }^{5}$ what risks must the parties involved be cognisant of avoiding ${ }^{6}$

This article will seek to explore whether players' economic rights ${ }^{7}$ can be used for securing lending, and if so, how might this security-taking technique be affected by insolvency or other credit risks. This will be achieved by drawing similarities between players' economic value and other types of non-debt assets that are choses in action in order to define the legal 'shape' of players' economic rights. The objective will not be to examine how a lender may come to believe that using players' economic rights as collateral is necessary, nor will it truly seek to engage with the normative questions which result from use: such as whether the value is justified, if the value can be properly or accurately

\footnotetext{
5 The loan agreement executed between Futebol Clube do Porto, Futebol SAD with Gool Company Limited and was found in Football Leaks, Football and TPO whistleblowing, 2 December 2015, https:// footballleaks2015.wordpress.com/2015/12/02/fc-porto-for-gool-co1td/ (accessed 20th November 2018).

${ }^{6}$ Whilst we use name-brand players, we recognise that often these players have substantial leeway over their destination. We seek not to engage with how this might complicate the matter of securing debtwe only seek to explore how a lender might use the expected, potential revenue of a transfer (to anywhere, of any player so 'earmarked') to hedge against lending through security.

${ }^{7}$ See below, defined as the rights for a club to create, to use, or to sell a player's employment contract within the football environment. It may take the form of a sale ("transfer") to other clubs, or it allows the club to have the player for them, profiting from the players' kit sales or his image.
}

tracked, nor whether the use is normatively desirable. We will instead seek to examine the systematic framework of an agreement. Can a transaction using players' economic rights be practically used, that is, enforced with a view of limitations in sporting rules and insolvency? The perspective then, through the lens of the above United example, will be with the view of the lender. How would a transaction work and what caveats might exist? As aforementioned, the result bears on financial and insolvency rules inside and outside the football world.

The format of the paper will be as follows; Parts 2 and 3 provide a primer on 'Football Regulatory Rules', a regime of provisions and regulations within the Fédération Internationale de Football Association ('FIFA'), the English Football Association ('FA'), and the Premier League ('PL'); governing football operations. Understanding the overlapping rules of FIFA, the FA, and the PL necessitates an exploration of the practical and football-system-related 'laws' governing the use of player economic rights to appreciate the 'shape' of player economic rights as an asset. These limit any potential transaction because, as will be clear, the utility of player economic rights (the thing used as collateral) is dependent on their use and value within the football community. Parts 2 and 3 will pre-empt Part 4 where the paper will examine what differentiates the value of a player from non-footballrelated assets at law. Without scrutiny, it will recognise the difficulties associated with valuation and examine the legal nature of player economic value. This is crucial in order to contextualise and understand where player economic value ('PEV') derives, the limitations of their use, etc. If player economic value (which differs, as the reader will see, from player economic rights,) operates in a legal sense, the same was as an asset that can be securitised-akin to a dematerialised securitisation $;^{8}$ then we may analogise how a lending agreement may use PEV as security. Market practice and Football Regulatory Rules suggest that player economic rights can and are used as security.

In light of the knowledge that player economic rights are used as security and having understood the barriers to player economic right use due to Football Regulatory Rules, 'Part 4' forwards two techniques which it is suggested to be most likely to achieve security-like results within the limitations of the Football Regulatory Rules set out in Parts 2 and 3. Thus, 'Part 5' constructs an agreement which attempts to ensure that the proposed transaction, using the United example, does not violate the limitations in Parts 2 and 3 whilst ensuring sufficient protection for the lender.

Constructing an agreement to comply with the regulatory framework involves a practical exploration of how a

\footnotetext{
${ }^{8}$ For the legal standing of dematerialised securities see, Eckerle $v$ Wickeder Westfalenstahl GmbH [2013] EWHC 68 (Ch); Also, Davies (2007); Gullifer (2012), pp. 377-410; McFarlane (2016).
} 
transaction might look. What is found is that a 'battle of the superseding regulations' produces a fragile state within the Football Regulatory Rules where uncertainty likely prevents any effective use of player economic rights. A transaction can be constructed to comply with the FA's rules but is strained to comply with FIFA rules, should the FIFA rules have direct effect. Crucially, in financial distress, it is legally doubtful for a transaction to make players' economic rights a viable asset, a fact especially true in English insolvency should exemptions in the Financial Collateral Directive not apply. Our United example highlights gaping issues in this financing technique for lenders.

The discussion in Part 5 will enable deeper exploration of how these techniques may reinterpret the limitations of player economic value as security for lenders where the borrower is near or has entered insolvency within 'Part 6'. Alongside the Football Regulatory Rules, insolvency is a major obstacle for lenders when taking PEV as security primarily because those regulatory rules limit aspects of security enforcement rights. Necessarily, this also explores the consequences the transactions in 'Part 5' would fit within the Financial Collateral Directive and Financial Collateral Arrangement Regulations set forth by the European Union which disapplies aspects of insolvency provisions and, in certain circumstances, may heighten the value of security over PEV.

Lastly, the paper will encircle the discussion with preempted questions, for example, whether such a practice ought to be done. It should be noted that this is not the central thesis of the paper but is necessary to highlight the ethical limitations on the practice. This involves a delineation of the moral and EU regulatory arguments ${ }^{9}$ which are likely to cross-cut the effectiveness of the aforementioned method in practice. This final stage does not, however, attempt to examine the substantive or practical benefits of using this form of financing for the club.

The goal is thus: To explore whether an agreement using/ exploiting value within player economic rights is possible, how it might look, and the private and commercial legal consequences which result. There will be no substantive engagement with the moral issues which may arise, however, valid they may be. This is not to dilute the importance of such a moral discussion; however, it is one better suited within a dedicated and separate paper.

\subsection{An example}

We imagine that United has opted to double down. It hopes to secure five players in this season's summer transfer market. For the sake of clarity, we shall use real players, but their

\footnotetext{
${ }^{9}$ Consider, Colomo (2005).
}

values will not necessarily be accurate as this paper does not seek to examine the valuation of the players; it merely assumes that they have a generally agreed upon valuation. United has procured the help from British Bank ('BB') in having the necessary funds to purchase five players on the market. Cristiano Ronaldo (worth $£ 80 \mathrm{~m}$ ), ${ }^{10}$ Lionel Messi (worth $£ 90 \mathrm{~m}$ ), ${ }^{11}$ Gianluigi Buffon (worth $£ 50 \mathrm{~m}$ ), ${ }^{12}$ Kylian Mbappe (worth $£ 110 \mathrm{~m}$ ), ${ }^{13}$ and Christian Benteke (worth $£ 20 \mathrm{~m}$ ). ${ }^{14}$ The loan totals $£ 350$ million pounds. It is an exceptionally large deal, well beyond what would ever happen. ${ }^{15}$ Putting aside the realistic possibility of these deals, we assume United does not have the necessary collateral to make BB comfortable. In all likeliness, BB would be required collateral for its own regulatory requirements. How would the transaction look if BB secured some of its debt using the value of the bought players? Conceivably, the cost of purchasing a player goes somewhere, and if BB is uneasy about lending United $£ 300$ million without security, perhaps they could use the outcome of the purchase. It must also be clarified that $\mathrm{BB}$ will not seek to secure the rights over specific players (i.e. secure Buffon or Mbappe). It should be rightly noted that players themselves have substantial leverage over where they go and when; clubs-and certainly not the lender-could do little to force a player to enter into a new contract. Furthermore, BB cannot precisely secure the debt using the value of the players directly. It will need to enter into an agreement to secure the club's proceeds of any given sale, careful not to capture any amount earmarked for the player or his agent. As will be shown, BB will instead seek to secure the entire 'stock' of United's player in an attempt to hedge the risk that specific players cannot be sold, or lose market value. ${ }^{16}$ The players will not necessarily be aware or even need to consent to the deal-the eventual

\footnotetext{
${ }^{10}$ With a fluctuating fictional player economic value (or resale) between $£ 71-100$ million. We note that the actual value is not necessarily indicative of the values we propose. We further note that the accuracy of the valuations will be difficult for clubs and lenders to ascertain, but there are robust systems in place to provide a relatively stable valuation of the asset. See Miao He, Richardo Chachucho, and Arno Knobbe 'Football Player's Performance and Market Value' Conference: Proceedings of the 2nd workshop of sports analytics, European Conference on Machine Learning and Principles and Practice of Knowledge Discovery in Databases (ECML PKDD), Porto, Portugal, September 2015; Also see the analysis done by Muller et al. (2017) pp. 611-624. The conclusions were that using crowd sourcing to valuate players were accurate, with variations being non-statistically significant, but overall averaging $3.4 \%$ lower than the actual sale values.

11 Fluctuating between $£ 80-130$ million.

12 Between $£ 32-65$ million.

13 Between £109-120 million.

14 Between £20-30 million.

15 We use an inflated loan value for the sake of using the players who would be attached to it, to dramaticise the example.

16 This will be further explained below.
} 
(individual) value of players is irrelevant because it is the aggregate proceeds of the club itself (not the value of the transaction as a whole) which BB will seek to securitise. We seek to make this clear through detailed, step-by-step analysis. We also note that this type of practice does occur currently within football transactions as evidenced by the $€ 5 \mathrm{~m}$ Porto FC and Gool Company financing contract found on Football Leaks and several Spanish league transactions, one of which resulted in a FIFA fine for Athletico Madrid. ${ }^{17}$ The existence of these transactions in practice (or at least the flirting of their use) in and of itself makes the research endeavour of this paper self-evident.

To understand the answer to the above example, one must understand what United is actually buying when they are said to 'buy' the players - how might the purchased players hold (potentially) unlockable value. Money spent on bringing players to clubs is not lost but is locked within the individual player-club employment contracts. The transfer price is the price to purchase an employment contract and is linked-very precisely - to the player and his contractual rights. ${ }^{18}$ These contractual rights are created for, and valid within, the football world. They are drawn from his employment contract with a given club. ${ }^{19}$ It is trite that a contractual right can be assigned and/or used as collateral. ${ }^{20}$ A player's value, as will be seen, thus derives from a club's ability to sell that player in the future and/or the revenue generated by better success on the field but is crucially linked to the employment contract between the club and the player and as will be shown, within a hermeneutic system of the football transfer market. It is already known that lenders use television rights, stadium naming rights, and cup winnings as security, but what if all these streams are already leveraged? Or what if, despite the $£ 300$ million in firepower, United fails to win and they are relegated, ceasing the increase income streams brought by winning football? Can a Bank use the future value of a player sold on the transfer market as collateral for its astronomical loan ${ }^{21}$ Can they force the sale of the players to attempt to recoup the money on the eve of United's collapse? ${ }^{22}$ We thus have a stage to examine

\footnotetext{
$\overline{17}$ The authors note that several London practitioners have commented on the existence of these types of collateral techniques.

18 Specifically, the right to terminate the contract and for the purchasing club to negotiate a new contract with the purchasing club.

19 Magee (2006).

20 Wolff (2005); The decision in Raiffeisen Zentralbank Österreich $A G v$ Five Star Trading LLC [2001] EWCA Civ 68 on choice of law is a clear demonstration of the difficulties arising from the characterisation of assignment.

${ }^{21}$ We suggest possibly, with substantial caveats set out below.

${ }^{22}$ We suggest perhaps indirectly, but only in circumstances wherein English law - an appointed administrator sells players to trade-out of administration.
}

further whether BB would be secured in an assignment of the players' future market value. As with the Porto FC agreement, it does not give proprietary rights to the lender in the player registration itself but is simply a commercial term of the loan facility. ${ }^{23}$

\section{Regulatory regime}

The handful of posed questions will be useful to keep in mind whilst exploring the taking of players' economic rights as security, but two additional queries will drive the framework of the paper's discussion: the uncertainties relating to how an agreement using player economic rights would/ could effectively be structured to reduce the credit risk of the lender whilst circumventing the aforementioned sport and property limitations. Two elements to this question exist. (1) Whether player value can be securitised (legally and under FIFA regulations) and what type of property right would be linked to it (clearly not a chose in possession because of FIFA third-party rules). ${ }^{24}$ (2) How would such a combination look, and would it be attractive for use by lenders? Additionally, does the created agreement comply with English insolvency law, specifically, does it produce a situation with sufficient protection from the contracting-out principle circumscribed in Football Creditors and/or in the event of default. ${ }^{25}$ This last matter asks crucially: does it provide sufficient remedy to a lender? As enunciated below, FIFA limitations on third-party ownership ('TPO') of player value would require security to be in the form of a floating charge. It should be noted that the proposed transaction is not a form of ownership in the vein of Sporting $v$ Doyen $^{26}$ (i.e. an investment or third-party ownership of economic rights for profit with an IRR proportionate to the share of the player's increased value, if any) but rather 'third-party ownership' only arises by way of a lender attempting to use the asset to realise protection for a debt, a fixed amount- the repayment would be the same regardless of whether the sold player is worth more than the collective loan. It might also be possible to secure using a derivative, possibly a synthetic asset-backed security ('ABS').

\footnotetext{
${ }^{23}$ Football Leaks (n 4).

${ }^{24}$ See Part 3 for FIFA Third-Party Ownership rules.

25 Football Creditors Case [2012] Bus LR 1539.

${ }^{26}$ CAS 2014/O/3781 \& 3782.
} 


\section{FIFA regulation}

Asking whether a player's economic rights could be securitised means determining whether the specified type of asset can be securitised. It requires close legal interrogation of the nature of the asset. As the player's economic rights exist within a sporting regime, composed of internal sporting rules, if one is to understand the limits of a player's economic rights, one must first understand the sporting rules which create it. A player's economic value is not akin to the value of a slave, for example. Instead, a player's economic value is the representation of his economic rights, which derive from an employment contract which is dependent on and operates within the sporting regime of football; it is symbiotically linked to the rules of football and does not retain its value when taken out of the 'football environment'. The complexity of what is precisely being sought to be securitised means that understanding the significance of the paper's objectives could easily be obscured by the complex and often dense regulatory framework of association football. Understanding and appreciating the limitations of sporting federations and private law allow for clarity in how similarities may be drawn between player economic rights and other forms of intangible assets which can be securitised. This section will explore the rules and enforcement regime set out by FIFA and its subsidiaries, such as the FA.

We have previously used the phrase 'Football Regulatory Rules' to describe the interlocking regulations, rules, and policies which govern association football. As will become clear, limitations set out in sporting association rules and property law necessitates specific arrangements are made to facilitate the use of PEV when securing debt. FIFA and FA rules operate as private international rules, categorised as arbitration rules, restricting the actions of constituent sporting clubs in ways that are more limiting than English private law. ${ }^{27}$ Ascription of/to said rules is voluntary but are mandatory if the constituent clubs wish to participate in playing football for profit. ${ }^{28}$ The rules are private international law rules for resolving disputes and map overtop of private law. While the matters concern civil and commercial matters, these conflicts of law rules fall outside the 12/15 Regulation as arbitrational awards. FIFA regulates relationships between clubs, associations, and leagues to produce a comprehensive regime of private international law relating to the sport itself. FIFA owns the sport of football and in doing so holds the right to restrict parties from participating in it. As discussed in Court of Arbitration for Sport: The effectiveness of CAS awards and FIFA compliance, FIFA creates both a political system which extracts compliance

\footnotetext{
27 Maciel (2016)

28 Ibid.
}

to its regulations through controlled access to the right to economic enjoyment of the sport as a 'quid pro quo', and it produces a private regime for conflict-resolution akin to private international law rules seen in Brussels I, II, etc. ${ }^{29}$

FIFA's monopoly on the sport and overlapping regulatory regime is implemented through relationships with 'member associations': national bodies which implement FIFA rules and govern, manage, and coordinate leagues from top divisions to recreational programming. In England, the FA operates as an umbrella association for two distinct leagues: the Premier League, consisting solely of the top division, and the Football League, which operates remaining provisional divisions. The leagues regulate clubs using their own rules and stipulate participation within various annual tournaments. Thus, three levels of Football regulations exist, separate and parallel to the national rule of law. The leagues (tier 1) are responsible to the domestic associations (in England the FA), with the domestic associations (tier 2) direct members of, and responsible to FIFA, which sits at the apex (tier 3). ${ }^{30}$ Clubs, who operate at the bottom of this regime, must comply with all 'tiers' of governing rules. FIFA rules traditionally apply directly to domestic associations, who are tasked with enforcing the broader-brush policies of FIFA; however, FIFA's ban on TPO operates in a way to allow FIFA to directly hold club's accountable for breaches of the rules. There is some lack of clarity over whether the direct effect of TPO is the desired - or perhaps even the intendedresult. As will be discussed, if FIFA's TPO rules are to truly operate with direct effect onto all tiers below as is claimed, then why do subsidiary regulators (the FA and Leagues) carve out exemptions which the FIFA rules do not? It will be shown that, it might be possible to envisage TPO rules to be applied akin to the EU principle of subsidiarity, ${ }^{31}$ i.e. the rule imposes an obligation onto all 'tiers', but the lowest competent body is expected to implement and regulate the ban (with FIFA only intervening where the rule has been inadequately applied.

What seems most likely is that FIFA's regulatory battle on TPO is a losing one, and as it loses its grip on enforcement, it is increasingly relying on the rule of subsidiarity to see to that the rules are enforced. As will be seen, the domestic association and club implementations of the TPO ban are

\footnotetext{
29 Ibid; Keohane and Martin (1995); Krasner (1982); Mitten (2014).

${ }^{30}$ It should be noted that an additional 'layer' exists where the FA must also report to UEFA, which represents all clubs and associations within Europe. UEFA is not mentioned here as its significance with regard to regulation of player economic rights is reduced when compared to the direct effect of FIFA and the FA. UEFA has not included any independent limitations on player economic rights beyond implementing FIFA rules on Third-party ownership.

31 Consolidated Version of the Treaty on European Union ("TEU”) [2010] OJ C 83/01, Article 5.
} 
not substantively the same, as a matter of interpretation, as FIFA's published ban. Thus, arises the uncertainty: is the wording of FIFA's ban to be conclusive and binding onto all parties-including clubs-or is it to only bind domestic associations to replicate the ban within their own rules? Some, including Geey, ${ }^{32}$ have suggested that the top 'tiers' operate as a secondary check, only engaging if the regulator believes its subsidiaries have inadequately applied the rule. ${ }^{33}$ It is an opinion which is consistent with Antoine Duval's analysis of FIFA regulations on working with intermediaries ('FIFA RWI') which has been noted for multiple national disparities in regulatory application of FIFA rules induced by 'FIFA's regulatory relinquishment' ${ }^{34}$ Geey's suggestion, as we explore below, an unsatisfactory answer. There are examples where FIFA has imposed sanctions directly onto clubs, as opposed to ensuring that the leagues enforce the rules. For example, FIFA regulations do not specify whether they are enforceable only at the national level against the member associations or whether they can be applied directly against clubs. What seems prevalent is that similar to FIFA RWI regimes, FIFA is quickly becoming unable to effectively enforce regulations and is relying upon subsidiary (domestic) associations to reign in club's third-party behaviours. ${ }^{35}$ The result is an inconsistently applied regulatory regime ripe for exploitation and uncertainty.

In theory, FIFA enforces rules first through its internal dispute tribunals and subsequently through the independent Court of Arbitration for Sport (CAS) ${ }^{36}$ CAS and Swiss federal judgments are a strong indicator for how rules will be interpreted because of their prominent legal positions with regard to FIFA. In examining CAS' judgments, it seems that FIFA rules, particularly those relating to player economic

\footnotetext{
$\overline{32}$ Geey (2009).

33 Ibid.

34 Antoine Duval, De- or Re-regulating the middlemen? The DFB's regulation of intermediaries under EU law scrutiny at the OLG Frankfurt, 6 October 2016, http://www.asser.nl/SportsLaw/Blog/ post/de-or-re-regulating-the-middlemen-the-dfb-s-regulation-ofintermediaries-under-eu-law-scrutiny-at-the-olg-frankfurt-by-antoi ne-duval-and-kester-mekenkamp (accessed 10 December 2018); cf Antoine Duval, Football Intermediaries: Would a European-centralised licensing system be a sustainable solution?-By Panagiotis Roumeliotis, 24 September 2018, http://www.asser.nl/SportsLaw/ Blog/post/football-intermediaries-would-a-european-centralized-licen sing-system-be-a-sustainable-solution-by-panagiotis-roumeliotis (accessed 10 December 2018).

35 Antoine Duval, De- or Re-regulating the middlemen? The DFB's regulation of intermediaries under EU law scrutiny at the OLG Frankfurt, 6 October 2016, http://www.asser.nl/SportsLaw/Blog/ post/de-or-re-regulating-the-middlemen-the-dfb-s-regulation-of-inter mediaries-under-eu-law-scrutiny-at-the-olg-frankfurt-by-antoineduval-and-kester-mekenkamp (accessed 10 December 2018).

${ }^{36}$ Ibid, see the discussion of the FA and Football League within Football Creditors Case [2012] Bus LR 1539.
}

rights, are applied with direct effect, meaning that FIFA does have the power to sanction clubs directly for failing to comply with the wording of their TPO ban. However, as will become clear, the direct-effect conceptualisation of FIFAthat is, whether FIFA rules apply directly to clubs-is done despite contradictory rules existing at lower regulatory tiers (i.e. the leagues and domestic FAs). Clearly, an inconsistency exists, and it is clearly being exploited. It might be that the conflict between the FIFA/Subsidiary rules operates in a manner similar to the rule disparities between FA and Football League rules examined by Daniel Geey wherein he concluded that FA consent will be required to allow the FL to regulate its league as it sees fit. 'Therefore although the FA rules $[. .$.$] appear more stringent than the FL's provisions,$ should the FA agree with the FL, that the FL will act to safeguard all FL [...] issues, the FA rules may be deemed somewhat redundant'. ${ }^{37}$ Yet, the proposal by Geey is unsatisfactory: it de-fangs the FIFA regulations and applies a principle of subsidiarity which leaves the system ripe for exploitation. National associations have been clear to express discontent over the TPO ban, leaving these associations to police the use is risky-it's the equivalent of entrusting the partying teenager with the keys to the liquor cabinet.

What relevance is our aforementioned analogy of regulatory 'tiering' for a collateral taker of player economic rights? To answer this question, one must understand more generally, a player's economic right. A handful of CAS jurisprudence following from the CJEU judgment in Bosman has resulted in the clear separation between player registration rights and economic rights. ${ }^{38}$ A Registration right is the right to register the player with the local football association and ostensibly have the player play for the registering club, established in RCD Mallorca v Club Athletico Lanus. ${ }^{39}$ FIFA rules limit the number of transfers which can occur per year by limiting the number of registrations a player can be subject per season. Registration rights 'cannot be shared simultaneously among different clubs' and have no economic value. ${ }^{40}$ They are not a proprietary right, despite some ${ }^{41}$ suggesting that registration is of value due to an associated pecuniary value. An Economic right is the right of the club to sell the player in the future for revenue arising from the transfer of a player's registration rights. Prior to Bosman, the economic right entrapped a player with the club irrespective of whether a contract for play existed. The Court held that this infringed on free movement of workers, and the resulting judgment liberalised the player transfer

\footnotetext{
37 Geey (2009).

${ }^{38}$ Rossi et al (2016).

39 CAS 2004/A/662.

40 CAS 2005/A/878.

${ }^{41}$ Rossi et al (2016).
} 
market and correspondingly creating a clear precedent on the two-part nature of player rights within sporting contracts. ${ }^{42}$ Thus, a player's economic rights are a derivative of the value of his employment contract. ${ }^{43}$ It is dependent on the football environment in order to retain its value, which may be personified by a 'player's economic value'. In our above example, Mbappe's $£ 110 \mathrm{~m}$ valuation is legally dependent on the contract for employment between him and the selling club.

The change from Bosman created two substantial and consequential shifts in the way players interact with sport clubs. Firstly, the ruling allowed for a legal division between registration and financial/economic rights. We know the conceptualisation is possible because registration and financial rights can be owned separately. In RCD Espanyol De Barcelona Sad v Club Athletico Velez Sarsfield ${ }^{44}$ the CAS recognised the ownership of economic rights as legally valid, deriving from the employment contract instead of deriving from registration rights:

in professional football a basic legal distinction is to be made between the registration of a player and the economic rights related to a player [...] A club holding an employment contract with a player may assign, with the players consent, the contract rights to another club in exchange for a given sum of money or other consideration, and those contract rights are the so-called economic rights of the performances of a player. This commercial transaction is legally possible only with regard to players who are under contract, since players who are free from contractual engagements - the so-called free agents - may be hired by any club freely, with no economic rights involved [...]. In accordance with the above distinction, while a player registration may not be shared simultaneously among different clubs, a player can only play for one club at a time, the economic rights, being ordinary contract rights, may be partially assigned and thus apportioned among different holders.

When players are said to 'go out on loan', it is a sale of temporary use of registration rights but not a sale of financial rights. Thus, clubs have found creative ways in order to separate each of the rights to achieve different objectives. The division has also brought forth the opportunity, and perhaps need, for non-football-related parties 'third parties' to finance and/or 'take ownership of all or part of the economic/financial rights to a player'. ${ }^{45}$ Said financiers would correspondingly enjoy an equitable portion of the profit upon

\footnotetext{
$\overline{42}$ McArdle (2000).

43 Magee (2006).

${ }^{44}$ CAS 2004/A/635.

45 Ibid.
}

the player's sale. ${ }^{46}$ The equitable investment is an investment into the sale of an employment contract, perhaps comparable to that seen in Don King. ${ }^{47}$ FIFA and the European Parliament have taken substantial steps to banning 'Third-party ownership' of economic rights ("TPO") and the influence of intermediaries. ${ }^{48}$ FIFA has done this through rules 18 ter and 18bis. ${ }^{49}$ Second, Bosman has heightened the cost of players and has coincided with a substantial increase in the financing mechanisms necessary to remain competitive. ${ }^{50}$

Extensive academic discourse exists attempting to quantify and examine the correlations between player age, contract value, pitch performance, and the value of an individual's financial rights. ${ }^{51} \mathrm{We}$ do not seek to engage in the debate over whether the valuations are overvalued; indeed, valuation of said rights will be empirically difficult. However, this does not mean that it cannot be done with accuracy. The value of a player's financial right (what we have phrased as 'a player's economic value') is a volatile asset but is an asset all the same. We may never know whether the recent sale value of certain footballers is justified. Undoubtedly, however, the 'player economic value', that is, the value of the financial rights for the clubs which own them, is realised on what is known as 'the transfer market' and is founded upon legally enforceable rights: these are valuations of yields from a contractual agreement-no different from a volatile over-the-counter derivative, or a Tesla share after a Elon Musk tweet. The value of a player is tied to the player's economic rights, deriving from the contract between them and the club. Realisation of this value is done by transfer to a second club. The tiering of regulations means that a collateral taker must be confident that an agreement using economic rights as collateral will be valid under all tiers if

\footnotetext{
${ }^{46}$ W. Tyler Hall, After the Ban: The Financial Landscape of International Soccer After Third-Party Ownership (2016), p. 192.

47 Don King Productions Inc v Warren and Others [2000] Ch 291.

${ }^{48}$ Also see, Sport Business, Uefa and European Commission to tackle transfer market issues, 22 February 2018, https://www.sport business.com/news/uefa-and-european-commission-pledge-to-tackl e-transfer-market-issues/ (accessed 20 November 2018); For Intermediaries see, Panagoitis Roumeliotis, Football Intermediaries: would a European centralised licensing system be a sustainable solution?, 24 September 2018, http://www.asser.nl/SportsLaw/Blog/post/footballintermediaries-would-a-european-centralized-licensing-system-be-asustainable-solution-by-panagiotis-roumeliotis (accessed 20 November 2018).

49 FIFA Regulations on the Status and Transfer of Players, 'V, Thirdparty influence and ownership of players' economic rights' Rules 18 bis and 18ter, 20-21.

50 The financial trouble that Mattock Rangers have encountered at the hands of a drawdown request at http://www.mattockrangers.ie/ news-archive/bond-scheme-2011-2016/, accessed 20 November 2018; Berg and Steffen (2015), pp. 1357-1392.

51 See those above at note 6; also see, Swanepoel and Swanepoel (2016).
} 
it is to be confident in the enforceability of their right to the player's economic rights. This is because the player's economic rights depend on recognition by the Football Regulatory Rules in order to legitimise its value. We realise that this is exceptionally complicated. If a lender secures collateral over an economic right and acts on that securitisation-taking control of the right themselves - if their retention of said right is not recognised in the Football community-i.e. since they are not a football-related party, the economic right they own is valueless because its value only exists within the football community between football parties. That is to say, if a lender takes collateral of an economic right- they are taking a right from an employment contract which only is effective within a specific environment-if they then go to sell the right to realise their debt, there will not be any buyers unless their possession of said right is recognised by the relevant authorities.

Moreover, even before the lender takes possession of the right, if their collateralisation is not recognised, it may well be valueless or at least at risk of being clawed back by Football regulators. Some will rightly recognise that the violation of TPO rules is a matter between the regulator (the FA) and regulated entity (i.e. the club) and that the regulator would have little power over the lender. To some extent this is true, but it also fails to recognise a crucial element of company law in England where it is possible for a corporate entity to argue that it did not have the capacity ${ }^{52}$ to enter into a contractual term, ${ }^{53}$ if the contracting counter-party acted in bad faith with the knowledge that the corporate entity exceeded its capacity. The contract would therefore cease to be valid. ${ }^{54}$ If the lender knows that the club could not lend-it would be an invalid contract. Presumably, of course, the lender would retain a claim in unjust enrichment for the money lent, but their position in or near insolvency would be substantially weakened by the lack of security. Secondly, while the regulators may not have the power to nullify the agreement, they certainly have the power to affect the club's right to play (and therefore the validity and value of the economic rights upon which the lenders' security depends); they may very well seek to remove the ability for the lender to take any collateral. An extreme example would be to nullify the player economic rights from the club or remove the club's golden share (which entitles the club to participate in football). As will be argued, this would place the lender in a precarious position where there is no longer an underlying asset to securitise. It is therefore crucial that if a lender seeks to use an economic right as collateral, they must ensure to avoid the barbed limitations set out by the Football Regulatory Rules.

\footnotetext{
52 For example, the legal right.

53 See Hammersmith and Fulham LBC [1992] 2 AC 1.

54 Companies Act 2006, s40.
}

We have previously highlighted how FIFA rules might be envisaged as analogous to EU laws in their supranational nature and direct-effect application. Some rules operate similar to regulations, where they require domestic national associations to produce an 'indirect effect' onto clubs. We have further learned that, with respect to using player economic rights as collateral, a lender is concerned with the economic rights. These rights are realisable, but limitations exist on the parties who can own player economic rights.

Whilst the FIFA rules on third-party ownership are said not to have a direct effect and instead apply at the national level with domestic associations applying the rules, ${ }^{55}$ the Swiss Supreme Court decision 4A_260/2017 upheld the CAS independence within a dispute wherein FIFA brought actions under Articles 18bis and 18ter (third-party ownership limitations) directly against a Belgian club, RFC Seraing. At an International law level, this indicates an implicit recognition of the ability of FIFA to enforce rules with direct effect, meaning FIFA is ostensibly justified, at least according to international law applied by the Swiss court, in applying its regulations directly against football clubs. Violation of FIFA regulations, regardless of what the rules are at the domestic level, could result in a CAS arbitration hearing, which may well sanction the club-a result which may not be detrimental to the collateral taker but would be detrimental to the club itself. A collateral taker ought to be cognisant of the FIFA TPO rules because whilst FIFA may not bring an action through the CAS, sporting sanctions can undeniably have material impacts on the revenue streams of clubs-a demotion or suspension, whilst harsh could substantially jeopardise the solvency of a levered club and ought to be of concern to a lender regardless of how collateralised he may be. (As will be shown, he will be unlikely to be very secure as most sport lenders do not rely on security.) Even if it was not directly effective, there is the risk that a national association could be held to violate FIFA may 'unzip' a transaction indirectly by sanctioning the domestic association for violating FIFA rules. Moreover, the fact that FIFA brought an action directly against the club suggests it is motivated to enforce its provisions with direct effect rather than merely against member associations such as the FA.

Regardless of whether an agreement could survive with no harm unto a lender, a club which violates would indubitably receive sanction from FIFA and/or the FA. It would not be in the interest of a lender to wantonly disregard the risks of entering into an agreement aware that the club is violating its contract with FIFA. Indeed, since Lumley $v$ Gye the courts have recognised that procuring a breach of contract is an English tort. The nature of the contract is immaterial so

\footnotetext{
55 FIFA Regulations on the status and transfer of the player, Article $3(1)$
} 
long as it is legally valid, performance has been deliberately interfered with, and a breach has subsequently occurred. ${ }^{56}$ The FIFA/FA rules are contractual clauses, and breach of those clauses provide specific and clear remedies for arbitration resolution. Whilst a matter which undoubtedly has far more intricacies than space permits be discussed, it seems pertinent to highlight. For instance, one may think that a lender would need to make substantial efforts to prove contracting to avoid a FIFA rule did not in practice amount to an intention to breach, or at least circumvent, the underlying contract between a club and FIFA and/or the FA. ${ }^{57}$

It will be of relevance to lenders-even those not engaging in collateralising player values-to understand how collateral will affect borrowers and how it will affect their security upon insolvency. We have in mind adjusting creditors whose interests in ostensible assets will change as borrowers become increasingly leveraged. We submit that regardless of any variation between the rules as implemented by the FA or FIFA, the strictest of the interpretations ought to be acceded, regardless of enforceability. To do otherwise would ignore the fact that a lender's agreement would be seeking to enforce a judgment which forced a borrowing club to breach a contract with FIFA. ${ }^{58}$

As a matter of comity and law, English courts will not enforce judgments that, by reason of making the judgment order, force or induce a party to breach a contract. In Regazzoni v K.C. Sethia, ${ }^{59}$ the House of Lords held that a contract was unenforceable since English courts do not enforce contracts, or award damages for a contractual breach, if the performance of said contracts involves doing an act which violates the law of a foreign state. Private International law is engrained within Swiss law, by participating in FIFA rules, associations subject themselves to the private international law rules which are themselves engrained in, and subject to, Swiss law. It ought to also be noted that FIFA's rules, whilst not the laws of a foreign state, are recognised by the English court as binding on the parties as a contract between party participants.

As will become clear, the tiering between regulatory rules has resulted in variation to the application of said rules. First, it is best to understand the environment where players' economic rights rest: both realisation techniques and limitations to their ownership.

\footnotetext{
56 This might be akin to the tort of inducing a breach of contract, Lumley $v$ Gye (1853) 2 E\&B 216; OBG Ltd v Allan [2008] 1 AC 1.

${ }^{57}$ For an in-depth discussion of this tort, see Jones et al. (2017) Chapter 24.

58 Maciel (2016).

${ }^{59}$ Regazzoni v K.C. Sethia [1958] AC 301.
}

\subsection{Transfer market rules}

With the record transfer value over than 100 million euros, the value of player economic rights is exorbitant. ${ }^{60}$ It is increasingly operating as the central method for association football clubs to generate revenues. Established by FIFA in 2009, 'The Transfer Matching System' seeks to track the transfer market and operate as a governance watchdog. ${ }^{61} \mathrm{It}$ might be noted that a player is a person and not an inanimate asset—but the rights deriving from their employment contracts are inanimate and are assets. Within the market, purchasing clubs will approach clubs with an offer comprising of a Compensation Fee. This is defined by the PL in its 2017-2018 handbook as 'any sum of money or other consideration payable by a Transferee Club to a Transferor Club upon the permanent transfer of the registration of a player'. ${ }^{62}$ If the value is acceptable, the purchasing club will have the opportunity to negotiate with the player a wage. If an agreement can be met, then the initial offer will be paid to the selling club and the contract between the player and the selling club is severed. The purchasing club then receives the financial and registration rights. ${ }^{63}$ The transfer fee therefore comprises of compensation for the early termination of a fixed-term contract payable by a prospective employer to an existing employer, however, it operates on a conditional precedent that a second contract is agreed by the prospective employer (club) and the underlying player. The type of transaction envisaged in the United example above acknowledges that the lender does not desire (and as will be seen in Part 3.2, cannot) to interfere with these contracts: i.e. it cannot force a player to enter into a new contract with a player. As will be seen, it is this point which snags the viability of a lender using player economic value as collateral (especially in insolvency).

\subsection{Third-party ownership rules}

Since the ban of TPO agreements in 2015, considerable academic discussion has focused on the legality and effect of a ban. ${ }^{64}$ The TPO-related FIFA Articles ${ }^{65}$ work in tandem to inhibit external influences on football, particularly on-pitch

\footnotetext{
60 Telegraph Sport, Paul Pogba completes Manchester United transfer for world record fee, 9 August 2016, http://www.telegraph.co.uk/ football/2016/08/09/paul-pogba-completes-man-utd-transfer-forworld-record-fee/ (accessed 20 November 2018).

${ }^{61}$ Marcotti, Gabriele, FIFA's Transfer Matching System a good step towards accountability, October 2015, http://www.espnfc.co.uk/blog/ marcotti-musings/62/post/2260996/fifa-seek-accountability-in-transfermarket-with-tms-system-gabriele-marcotti (accessed 20 November 2018).

62 PL Handbook 2017-2018 'Definitions' A.1.38.

63 Dobson and Goddard (2001), p. 23.

${ }^{64}$ See for example, Duval et al. (2016), pp. 233-252.

65 Article 18ter and Article 18bis.
} 
interferences ${ }^{66}$ and limiting third-party ownership, that is, non-football-related parties from owning a part or the whole of players' economic rights. Academic dialogue of the practice has primarily focused on the technique being used to realise profits and has examined the legitimacy of the rules as enforceable in view of European Union competition laws. In other words, it was seen as a form of investment by the third parties and interested parties have sought to limit the ban through EU regimes. The corresponding result had been that profit horizons of thirdparty investors posed serious risks to the integrity of preventing third parties from influencing football-related decision-making. That is to say, when using player economic rights as third-party investment vehicles, the threat of those investors affecting what players played, when they were transferred, and for how much - no longer remained in the control of the club. Yet, little study has gone beyond the aforementioned lense.

The regulatory tiering of Football Regulatory Rules means that FIFA rules apply directly to the FA, whether they apply to clubs has been shown to be a matter of uncertainty. Regardless of the reach of FIFA's rules, the FA is meant to implement the FIFA restrictions on TPO without amendment, ${ }^{67}$ allowing application to member clubs. This would mean that in our example, United would draw its rules from both the PL and the FA, and they would need to be aware of the risk of sanction by FIFA as well.

It has been seen that FIFA rules are occasionally enforced directly. Furthermore, FA rules were applied with amendments, ones which alter the intention and policy of the restrictions. In some ways, this is a battle of the forums (or rather 'a battle of the regulations'), with each authority casting different sized nets to restrict club activity. The ultimate question must then be: who does United follows? While collateralisation of a player's economic value is not, strictly speaking, third-party ownership; the regulatory wording of FIFA's stance on TPO means that granting a security right would be entrapped within these regulations. A lender must be aware of these caveats.

The differences between the substantive wordings of the various association/authority rules relating to club activities produce considerable uncertainty with regard to the scope and the application of the rules. A hierarchy between the various regulating authorities would suggest that FIFA rules trump all; however, the lack of exception-carve-outs within FIFA regulations is cause for concern. Two overarching rules concern our efforts of security-taking PEV and are relevant to the reader. Those relating to ownership of PEV and influence. We will begin with influence.

\subsubsection{Influence}

Article 18bis regulates third-party influence and ownership of players' economic rights. It is designed initially to root

\footnotetext{
$\overline{66}$ Hall (n 46) 192.

67 Article 18ter and 18bis.
}

out undue influence stemming from financial powers. The English version of the Regulations on the Status and Transfer of Players states:

1. No club shall enter into a contract which enables the counter club/counter clubs, and vice versa, or any third party to acquire the ability to influence in employment and transfer-related matters its independence, its policies or the performance of its teams.

2. The FIFA Disciplinary Committee may impose disciplinary measures on clubs that do not observe the obligations set out in this article. ${ }^{68}$

(emphasis added)

The operation of the clause turns upon the ability to influence in various club-specific matters. Judgments before the courts on the FIFA are limited arbitration judgments from the CAS relating to Article 18bis have been extensive, ${ }^{69}$ but only a limited number of judgments have been in English or critically examined the exact wording of the FIFA rules. Most have focused on the legitimacy of the ban as a whole. One must presume, however, that the regulation means 'actual' or rather 'direct' legal influence. FIFA's objective is to restrict agreements designed to influence employment or the independence of the club's football-related business, 'its policies or the performance of its teams, ${ }^{70}$ Surely however, the clause cannot be read so widely as to include any potential influence. If it was, then it would seem that any type of financing would have the potential to 'influence' decision-making. If a club made a loan agreement unrelated to transfers where its repayment eventually became unsustainable because of poor club performance; then surely this agreement could not be said to engage Art.18bis if the club subsequently chose to sell players in order to maintain its ability to pay its debts. We note also that Art.18bis para 2 implies that the clause operates with direct effect. It is known that the rule is also applied at individual association and league levels as well. Within England, the FA has additional conditions on financial arrangements relating to player registration in the Rules of the Association. ${ }^{71}$ Here, FIFA's

\footnotetext{
${ }^{68}$ FIFA 'Regulations on the status and Transfer of Players 2018', 20 (2018).

${ }^{69}$ CAS 2011/A/2653; CAS 2016/A/4490; Antoine Duval, EU Law is not enough: Why FIFA's TPO ban survived its first challenge before the Brussels Court, 25 August 2015, http://www.asser.nl/SportsLaw/ Blog/post/eu-law-is-not-enough-why-fifa-s-tpo-ban-survived-befor e-the-brussels-court1 (accessed 19 November 2018).

${ }^{70}$ Article 18bis.

${ }^{71}$ Rules of the Association 2017-2018 Part C.1(b)(iii) 'Rules Relating to Players'.
} 
18bis is complimented by the specification that clubs cannot enter agreements where parties may 'influence materially' the club's policies. ${ }^{72}$ We submit that this is a higher burden than that set out in 18bis. ${ }^{73}$

Two things are clear in the rules of third-party influence on club staffing and playing decisions. First, the rules are designed to prevent undue/undesired influence from seeping into the football community. Undeniably this is a good thing. Second, the rules could affect a security taker in a tangential manner where enforcement of security affects the decisions of a club. A lender will seek to avoid that risk, outlined below. Until then we turn to the question of ownership.

\subsubsection{Ownership}

Article 18ter concerns ownership of players' financial rights. This relates specifically to the type of parties which are authorised to own these rights:

1. No club or player shall enter into an agreement with a third party whereby a third party is being entitled to participate, either in full or in part, in compensation payable in relation to the future transfer of a player from one club to another, or is being assigned any rights in relation to a future transfer or transfer compensation.

2. $[\ldots]$

3. $[\ldots]$

4. $[\ldots]$

5. [...] all existing agreements covered by paragraph 1 need to be recorded within the Transfer Matching System (TMS). All clubs that have signed such agreements are required to upload them in their entirety including possible annexes or amendments, in TMS, specifying the details of the third party concerned, the full name of the player as well as the duration of the agreement.

6. The FIFA Disciplinary committee may impose disciplinary measures on clubs or players that do not observe the obligations set out in this article.

Art.18ter inhibits third parties from being assigned any rights over the transfer or directly resulting compensation. Art.18ter para 1 not only restricts assignment, but it limits any form of transfer of the players' economic rights. We

\footnotetext{
72 This is complimented within the FA Complete Handbook 2018 'Third Party Interest in Players Regulations,' p. 304.

${ }^{73} \mathrm{Cf}$ the debate on the word material such as material adverse change, Grupo Hotelero Urvasco SA v Carey Value Added [2013] EWHC 1039 (Comm); See also, Rawlings (2012).
}

suggest this includes equitable assignment as it states a ban on third parties 'being entitled to participate [...] in compensation [...] or is being assigned any rights in relation to a future transfer' ${ }^{74}$ the operable words here must be 'any rights' and secondly, 'ownership'. First, if 'any rights' or 'ownership' includes equitable rights, then an assignment of the economic rights is not possible. Without the inclusion of equitable rights, the clause would clearly be devoid of its intention as it only would be referring to statutory/legal assignment and lack the comprehensive 'teeth' FIFA clearly sought in imposing a blanket ban.

Again, the article implies direct effect, but the battle of the rules continues, as Art.18ter is replicated in a modified manner in the Premier League (PL) rules through U.38 and V.30 which applies with respect to Rule U.38.10. Rule U.38 addresses similar areas as Articles 18ter and 18bis, it does so at a much more granular level. Rule U.38 specifies that a club can make payment or incur liability because of a transfer by receipt of a 'Compensation Fee, Contingent Sum, Loan Fee, or sell-on fee, in default of a payment by the Transferee Club from which it is due, from: a Financial institution or other guarantor'. ${ }^{75}$ Rule V.30 specifies that a club may assign its entitlement to a Compensation Fee pursuant to Rule U.38.10 so long as it instructs the Transferee Club to pay the assignee as it becomes due. The rule further stipulates that a transferor club may pay or incur a liability in connection to a registration/transfer 'by assignment of its entitlement to a Compensation Fee to a Financial Institution' ${ }^{76}$

The FA houses similar rules as Article 18ter within 'Third-Party Interest in Player Regulations 2017-2018', found in the FA Complete Handbook prohibiting clubs. Baring exceptions, ${ }^{77}$ clubs:

may [not] enter into an Agreement with a party whereby that Club: makes or receives a payment, whether directly or indirectly, or; assigns, novates, sells, grants, acquires, or otherwise transacts in any right or obligations whatsoever, $[\ldots]$ to, or from that [third-]party as a result of [...] the proposed or actual registration, or; the transfer of registration, or; the employment or continued employment by the Club of a player. $^{78}$

This is entirely conclusive. Unless an exception is specified by the FA that no third party can hold any interest, this must include an equitable assignment. Therefore, it seems clear

\footnotetext{
74 FIFA Regulation on the Status and transfer of players (2018).

75 U.38.3 and U.38.3.1.

${ }^{76}$ U.38.10.

77 Regulation B "Permitted Club Agreements".

${ }^{78}$ Part A.2.0.
} 
that direct equitable assignment of players' economic rights is not possible within the private international law system of the Football Regulatory Rules. These rules operate as a clamp on the types of security a lender can take. As previously mentioned, the enforcement of an assignment might be valid at law but places the counter-party, the football club, in violation of Football regulatory rules.

\subsubsection{Carve-outs}

We observe that FA and PL rules carve-out exceptions to the FIFA bans through a number of exceptions, "permitted' agreements. ${ }^{79}$ These carve-outs provide avenues for third-party financial institutions to collateralise debts with assigned player sales. No equivalent carve-out rules exist within FIFA regulations, and there exists no guidance on the interpretation of FIFA regulations 18bis and 18ter other than what is written in the regulations themselves. The question remains whether the carve-outs are valid or violations of the FIFA rules. The regulatory tiering places FIFA and its Dispute Resolution Chamber at the apex, with the CAS operating as an appellate court. As demonstrated above, FIFA's ban on third-party ownership ostensibly has direct effect. ${ }^{80}$ Article 8.3 and specifically 11.4 (a) of the FIFA Statutes impose mandatory provisions of compliance of all FIFA regulations and statutes. This is reflected in FA rules. Rule B.1 of the Third-Party Interest in Players Regulation caveats the rules are 'subject always to FIFA' regulations. However, the FA exemptions, that a club is authorised to collateralise financing agreements by securing them against Compensation Fees or other receivables,${ }^{81}$ is not congruent with FIFA guidance. ${ }^{82}$ When read in tandem, Articles $18 \mathrm{bis}$ and 18ter could not allow for the exceptions the FA and PL have set out with regard to securing of Compensation Fees. The FIFA Commentary on the RSTP states that domestic associations are responsible for regulating domestic transfers between clubs of the same association and that 'as a general

\footnotetext{
79 B.1.7 through B.1.12.

${ }^{80}$ See Part 3 above.

81 B.1.7 through B.1.12. Per C1.15 the Club must lodge the completed agreement along with support documentation within 5 working days. D.6 outlines that 'wherein a club proposes to enter into borrowing that is secured against, or has a return directly linked to the value or future value of any player employed by a Club may be approved subject to such conditions as may be required by the association from time to time'.

${ }^{82}$ Indubitably further research will need to be done to examine the disparity between FIFA and FA rules on Third-party ownership implementation. An attempt was made to examine major European league rules (particularly German, Italian, and Spanish), but a reliable English translation was unavailable before the time of publication. What is known is that extensive research was conducted on FIFA Regulations on Working with Intermediaries (RWI) found that
}

rule, FIFA does not interfere with the day-to-day business of the associations, provided that severe infringements of the FIFA statutes do not occur.(emphasis added) ${ }^{83}$ Clearly then, FIFA's regulations apply overtop FA rules when FA rules are incongruent with FIFA statutes. Frustratingly, this does not proscribe whether FIFA rules are read narrowly (to exclude transfers of the kind the FA authorises) or widely (to therefore accommodate FA rules). In Club Athletico Penarol v Carlos Heber Bueno Suarez; Cristian Gabriel Rodriguez Barrotti \& Paris Saint-Germain, ${ }^{84}$ the panel emphasised the need for uniformity and (akin to the EU rules) universality. Yet, it is clear that the rules are imposed inconsistently and the current state of TPO rules demands further research into the effects of divergence. We suggest that the FIFA rules must be read narrowly in order to allow activity which the FA permits, thus allowing assignment of Compensation Fees resulting from player economic rights. To do otherwise would likely capture certain club activities not intended by FIFA. Even still, FIFA rules are clearly more restrictive than those produced by the FA and they are inflexible in their application.

Taking security of player economic rights by financial institutions is both commonplace and permitted within England. The most restrictive limitations derive from the FIFA rules. The development and subsequent ban of TPO in association football highlight a bright line in which a collateral taker will not desire to cross. Avoiding TPO rules will thus be crucial for determining the nature of the transaction which best fits securing a lender. However, the ban within 18 bis and 18ter is designed to attack a mischief different from secured lending, and it is submitted that the continued allowance of a difference between FA and FIFA rules is because the FIFA articles are not designed to restrict secured lending. It still remains odd, however, that FIFA's regulations did not specify exceptions if it had intended them. Moreover, an implicit ignorance to market practice does not equate to authorisation.

In concluding this section then, one might now appreciate the permissibility of taking security over the Compensation Fee of a player transfer, at least in England. The broader cast of the FIFA regulations on the status and transfer or

\footnotetext{
Footnote 82 (continued)

the piece-meal de-centralised implementation of the rules on RWI created drastic disparities between regulatory rules, Antoine Duval, De- or Re-regulating the middlemen? The DFB's regulation of intermediaries under EU law scrutiny at the OLG Frankfurt. By Antoine Duval and Kester Mekenkamp, 6 October 2016, http://www.asser.nl/ SportsLaw/Blog/post/de-or-re-regulating-the-middlemen-the-dfb-sregulation-of-intermediaries-under-eu-law-scrutiny-at-the-olg-frank furt-by-antoine-duval-and-kester-mekenkamp (accessed 19 November 2018).

${ }^{83}$ FIFA Commentary on the Regulations for the Status and Transfer of Players (2018).

84 TAP 2005/A/983 \& 984.
} 
players still ought to remain a concern for lenders-not all are financial institutions and clubs clearly remain within the direct effect of FIFA rules-regardless of what the FA rules specify. In appreciating these facts, we may continue forward to better understand PV. How ought player economic rights be construed as security and, further, what are the consequences upon insolvency?

\section{Differentiation}

What is fundamentally different between players' economic rights and other forms of assets used as collateral? Several limitations on the rights restrict their utility to borrowers, and thus, lenders ought to be cognisant of them. (1) It cannot be possessed by parties outside of the FIFA-determined sporting community for want of violating Articles 18ter and 18bis. This has enforcement and insolvency consequences. (2) It is measured by performance and the duration of a contract, the first of which is empirically difficult to measure and volatile. The solution to said problem may be to include margin. In our example, BB may wish to take security over $£ 360$ million of player economic value using conservative estimates. They do not think Ronaldo, or any of the players could fetch the value that they were purchased for. In such an example, United may add another player, perhaps Paul Pogba, to the list of players who would be sold to cover the collateral of the loan. Now, the $£ 350 \mathrm{~m}$ used to buy five players is secured using the revenue generated from the sale of six players.

In terms of categorisation, CAS jurisprudence clarifies that a players' economic rights are the rights of the club to transfer the player. This is a right deriving from and related to a contractual obligation. We submit that these are the rights to the proceeds of the sale. We call the realisable revenue resulting from a player's economic rights, PEV. It is submitted that, in light of the limitations set above, players' economic rights cannot be necessarily posted as collateral to an obligation towards a non-football third party. Some form of conversion is necessary to avoid direct ownership of players' economic rights by the collateral taker.

With regard to aspect 1 , the economic rights of a player are intangible choses in action dependent on the existence and validity of the employment contract between player and club. It can neither be under the control of non-footballrelated parties, nor can they be secured through self-help. They are contractual rights. The first statement leads on from the fact that the economic rights of a player's value are limited, if not useless, without the corresponding registration rights. Players' rights (registration and economic) only function within the football ecosystem, as seen in Football Creditors, these are dependent on participation within a football league. In this way, the crucial element of players' economic rights which a lender will be interested in is the proceeds of the sale of a player's economic rights, what we have previously categorised as player's economic value. ${ }^{85}$ Thus, a lender will be looking to securitise its lending activities using a contractual right to a realisable value of a player's economic rights on the transfer market. To avoid actual ownership and enjoyment of the player's economic rights, it seems probable the security must not be for the rights themselves but for their proceeds. We submit that the proceeds differ, at least in English law, from the rights analogous to the differentiation established in the line of cases leading to Re Spectrum Plus. The proceeds of a player sale, the realised value of selling players' economic rights is, we submit distinct from the right to sell a player. The right to sell a player is a right associated with a contractual agreement between the club and player. The distinction falls along the divide between right to payment under a contract and the right to the proceeds of that payment. The proceeds, by contrast, arise when the original is extinguished ${ }^{86}$ Extensive case law has borne the difference between book debts and their proceeds ${ }^{87}$; the player's economic rights might be seen as a contingent debt. This differentiation is necessary in order to prevent lenders from creating a security which interferes with football regulatory rules, as these are more stringent than the limitations of English law; the football rules will be important for a lender to navigate to ensure collateral remains enforceable and ensure its counter-party (the club) is not in breach of said rules. Alternatively, one might refer to Don King Productions Inc $v$ Warren and Others, ${ }^{88}$ where a restriction on assignment was held not to prevent a declaration of trust from taking effect.

Thus, we submit that, in light of the Football Regulatory Rules relating to third-party ownership, a lender must seek to enforce against the proceeds. Direct enforcement would be valid under FA rules but not FIFA, whereas receiving the proceeds would be valid under both. To further clarify why this is the case, it might be useful to delineate that whilst comparable to a book debt (examined in further depth below), players' economic rights are not a cash-flow-generating receivable. Unless the player has already been sold and the proceeds have been agreed to be paid on a periodic basis, the unrealised value of a player's economic rights does not generate revenue. There are exceptions to this, of course. 'Loaning' a player—an event where a club will sell

\footnotetext{
85 cf the Swiss Constitutional Court's dialogue on validity of such a contract in Doyen $v$ Sporting.

${ }^{86}$ Re Spectrum Plus Ltd (In Liquidation) [2005] 2 AC 680, 721; Also see, Benjamin (2007), p. 468.

${ }^{87}$ Northern Bank Ltd v Ross [1990] BCC 883; Don King Productions Inc v Warren and Others (No 2) [1998] 2 All ER 608.

${ }^{88}$ Don King Productions Inc $v$ Warren and Others (No 2) [1998] 2 All ER 608 .
} 
the registration rights for a specified duration, retaining the financial rights-is one example where cash flow may be produced by the club's control of a player's rights. So, players' economic rights are not a cash-flow-generating receivable. We might, however, conceive the players' economic rights as a conditional debt obligation, the value of a player's rights to the club can only be realised by the rights being purchased by another club within the football ecosystem. Realisation of this value is dependent on the commitment of another club to pay. The debt is conditional on (1) a club agreeing to the valuation of the player and (2) the transfer finalising. From the perspective of the selling club, a string of completed player transfers seems functionally not unlike a collection of debt obligations such as mortgage or credit card obligations. Further, the retention and enjoyment of the player rights are conditional on a club's solvency. ${ }^{89}$ With this in mind, a clear framework for security taking is necessary to inform lenders the additional risk the practice may involve, especially within insolvency.

If it is admitted that any security over a player cannot give the lender possession or control over the player's economic rights or their direct compensation fees, then a lender could create a charge over future book debts owed to the equivalent value of a collection of the player's economic rights. It is trite law that future assets, including book debts, can be subject to a charge..$^{90}$ As will become clear in the example below in Part 5, direct benefit to proceeds ought to be avoided. We have previously established that there is a broad discrepancy between FIFA rules and their implementation through the FA. The FA rules provide carve-outs for financial institution lending transactions using players' economic rights as security, but no such carve-out has been permitted through FIFA. Having previously sought to construct a transaction which would remain effective against both the FA and FIFA rules, taking security will necessitate that the transaction will comply with the more stringent of rules, those being FIFA. It will be vital for the proceeds of a sale to not explicitly be designated for the lender. This will weaken the strength of taking security if insolvency occurs at certain points in time, and may be undesirable for some lenders, but would be necessary to avoid FIFA third-party ownership rules. With that said, because FIFA does not apply against clubs with direct effect, some confidence can be had that assignment of player economic rights under FA rules would be enforceable, at least to the extent that the lender is a financial institution within the exemptions of the FA rules.

Why is differentiation important or even relevant? The practice of using the realisation of players' economic rights as collateral is common, and even if it were not, exploring whether PEV could secure lending could provide the

\footnotetext{
89 Football Creditors Case [2012] Bus LR 1539.

${ }^{90}$ Holroyd v Marshall (1862) 10 HLC 191.
}

efficiency and economic advantages of secured lending to clubs. ${ }^{91}$ Properly understanding what the collateral is, and the viability of the collateral, as collateral, is important. If lenders are using players' economic value as collateral when enforcement and realisation are unrealistic, then creditors are unlikely to be pricing the cost of the transaction correctly.

Having attempted to draw comparisons between various intangible assets and receivables to a player's economic value, a clarified image of what a player's value is and what it is not has appeared. The player value to clubs is an intangible asset representing the value of a future, conditional receivable. Said receivable is conditional on a set of footballrelated circumstances. It rarely produces cash flow prior to its conversion into a receivable of equivalent value. Prior to conversion, it is not redeemable nor is the value realised without the occurrence of those events. It further cannot be redeemed or possessed by non-football-related parties.

\subsection{A return to example}

What is clear from the above canter through the Football Regulatory Rule regime is that there is a tightly wound array of rules which cover the same substantive matters: i.e. the rights which derive from player employment contracts and the parties who are authorised to use and possess those said rights.

We might now return to our aforementioned example to contextualise what has been learned: BB cannot hold a direct interest in a player, due to the substantial regulatory risks of financing in relation to direct interests in players registrations-and few, if any-clubs would be willing to burden the risk of sanction. However, BB might be capable of taking an indirect interest. What if BB took an interest in the proceeds of the sale of players? A critic might highlight that the average playing contract only being between 3 -yearsthe value of securing against a employment contract would depreciate quickly - however, that is not unlike other assets, most electronic technologies have an accounting depreciation of almost $70 \%$ and yet lenders still are willing to use it as security against lending. ${ }^{92}$ Even still, a player's influence over his ultimate destination is considerable and it might not always be possible for United to sell Pogba, Ronaldo, and Messi. Instead, BB might take security over the proceeds of an entire class of players-perhaps a running list of United's first team sheet: if any of the players are sold, then might BB

\footnotetext{
91 By this, we mean that it provides the opportunity to use an asset traditionally un-liquidated and enable it to unlock reduced costs of lending which is associated with secured lending.

92 Accounting depreciation GAAP, following IRS depreciation value of computers is over a period of 5-years.
} 
take security over the proceeds of sale? What type of effect might this have on BB's security in the event of insolvency?

Thus, as we have attempted to make clear, the player's identity seems to be irrelevant. We might remind readers here that the objective of the paper is to critically examine a phenomenon which exists in practice and to scrutinise its function: how might it work and how might it fail, what are the pitfalls for both lender and borrower? In view of the regulatory regime above, it is clear that substantial hurdles will need to be overcome for a lender to actually have reliability in their collateral.

\section{As collateral}

It has been suggested that to navigate the Football Regulatory Rules, taking players' economic rights as security could take the forum of one of two methods: (1) a derivative, referenceable to the proceeds, in the shape of an asset-backed security, converting an insurance policy to collateral ${ }^{93}$, or (2) a floating/fixed charge over a book debt. If one is to admit that the aforementioned rules are stringent and directly effective, then the proposed schemes are, ostensibly, a primary method to avoid becoming entrapped within the limitations of enforcement which result from the Football Regulatory Rules.

\subsection{As asset-backed security}

The first of two methods explored is utilising an ABS method to collateralise a debt provides two options for a lender. This has been previously used in the United States securitising the earnings of American National Football League athletes, ${ }^{94}$ and of course extensively to securitise ticket earnings with the Rangers and, catastrophically, at Leeds United. ${ }^{95}$ How then, would an ABS avoid the TPO requirements whilst also ensuring adequate risk protection? The advantage of an ABS is its function as a converter of risk from the originator (the club who bears the risk of the assets) to investors, who purchase notes issued by the special purpose vehicle ('SPV'); often this is done without a true sale of the asset. ${ }^{96}$ The

\footnotetext{
93 Akin to a catastrophe bond, See Benjamin (2007).

94 Dan Weil, Securitization of Athletic Performance Lacks Super Bowl Ring' Institutional Investor "Corner Office, 7 February 2016, https://www.institutionalinvestor.com/article/b14z9mtq8smg1n/secur itization-of-athletic-performance-lacks-super-bowl-ring February 07 (accessed 19 November 2018).

95 BBC Sport, Former Chairman Alastair Johnston delivers Rangers cash warning, 1 February 2012, https://www.bbc.co.uk/sport/footb all/16830169 (accessed 19 November 2018).

${ }^{96}$ For further understanding of an ABS structure, see Benjamin (2007).
}

issuing of notes from the ABS is advantageous in that it broadens investors and further allows conversion of securing lending on player value beyond financial institutions to other financial market participants. ${ }^{97}$ Two possibilities exist within the 'as ABS' category, but it is conceivable other structures could achieve the same balance of adequate enforcement and avoiding TPO regulations. A synthetic ABS which references the value of a player through insurance contracts, or a traditional ABS which has been assigned the proceeds.

\subsubsection{Synthetic ABS}

A Synthetic ABS would replicate the cash flows incident to ownership of players' economic rights, without actually having ownership of the rights. This is achieved by holding a portfolio of low-risk assets such as triple A-rated assets. ${ }^{98}$ It is 'synthetic' because the ABS uses a derivative as a core of the ABS asset-base. In our example, the derivative might be a total return swap or credit derivative is issued by the lender as protection seller and is referenceable to the realisation of all club transfers relating to players. ${ }^{99}$ The advantage of this form is that no transfer of the player rights occurs.

\subsubsection{Traditional ABS}

As Benjamin highlights, under a traditional ABS, receivables are either assigned or transferred to a SPV which is insolvency adverse. ${ }^{100}$ In making the SPV insolvency adverse, the note holders are unlikely to be able to exert third-party influence on the club. ${ }^{101}$ The SPV raises funds from investors and uses those proceeds to pay the originator of the asset. ${ }^{102}$ In turn, the investors receive notes which include payment obligations secured by the purchased assets. ${ }^{103}$

Several issues exist with a traditional structure, one of which is they are likely to become entrapped by the TPO provisions if the proceeds of the player economic rights

\footnotetext{
97 Burns (2007).

98 Benjamin (2007), p. 410.

99 ABS structures have long been used to securitise player and club IP royalties, image rights etc-these could compliment the PEV. However, since they are not the centre of this paper's discussion, they will not be examined in depth here, see Ali and Robbe (2004), p. 2.

100 Benjamin (2007), pp. 406-407; Aragon v Pender [2005] 1 WLR 3412 at 3416 Parker LJ; Ayfin Opal Luxco 3 SARL $v$ Windermere VII CMBS [2016] EWHC 782 (CH), [9] (Snowden J).

101 Gemini (Eclipse 2006-3) PLC v Danske Bank [2012] EWHC 12, [6]-[11].

102 Credit Suisse Asset Management LLC v Titan Europe 2006-1 PLC [2016] EWCA Civ 1293.

103 Benjamin (2007), pp. 406-407.
} 
are legally assigned. Even if there were not the case, it is secondly not preferable because it does not provide remedy for the risk of insolvency as outlined in 'Part 5.2' below. By contrast, a synthetic ABS does not take assignment but would either use a referenceable derivative or an insurance agreement to securitise the rights and allow the lender to issue shares. Depending on the terms, an ABS assignment may violate the FA or FIFA rules. We reiterate again that taking collateral in players' economic rights cannot be direct. As the Football Regulatory Rules restrict transferability, ${ }^{104}$ novation is clearly not an option. A silent assignment at equity may fall within the FA exemptions if the lender is a financial institution and even if not, would likely remain valid due to the fact that it does not require disclosure to the football authorities; however, it would be difficult for the SPV to enforce if a club were financially distressed. A third option of participation is entering into an equal and opposite position, a technique common on derivatives markets; transfer by closeout could affect a transfer of the proceeds without affecting the Regulatory Rules. ${ }^{105}$ Alternatively, the ABS could be used in tandem with the method proposed in Part 5.2 where the proceeds of the player are placed into an account and the account is either held on trust or under a floating charge for the SPV. ${ }^{106}$

The insolvency adverse nature of an ABS will protect the initial lender by moving risk to third-party investors. ${ }^{107}$ The risk of realisation would not disappear, however, it would merely move from the lender to ABS investors, meaning that, depending on the ABS investor's appetite for risk, understanding the rights to a player's economic value will be relevant to the asset originator (the lender) and the investors. An ABS would still require an assignment of some kind, and therefore two questions would be relevant: (1) whether the assignment was valid, and (2) the rights the ABS investors ${ }^{108}$ have in the event of default. Thus, even though an ABS shields the lender against an insolvency event, the lender would still need to be aware of the insolvency risks.

\subsubsection{Insurance}

PEV ABS might additionally take the form of an insurance transaction, either a CAT bond or an insurance position securitisation. ${ }^{109}$ Whilst this method does not require an

\footnotetext{
$\overline{104 \text { See Part } 3 .}$

105 Benjamin (2007) 25.08; also see, Simpson (1991), p. 194.

106 As suggested by Benjamin (2007) 18.14 .

107 Aragon v Pender [2005] 1 WLR 3412, 3416; Citicorp Trustee Co Ltd v Barclays Bank PLC [2013] EWHC 2608.

108 Where the lender is an institution the issued securities could be used as collateral within the FCAR regime, possibly benefiting the lender within financial capital requirements.

109 Benjamin (2007).
}

interest in the players' economic rights being acquired, the disadvantage is that such a method would not 'float' above the club's squad; insurance policies would underwrite specific players. In our example, United's five players would be insured for a value equivalent to the loan so that the insurance contract matures in the event of default of United and sale of the players. In comparison to using a floating charge or an ABS, an insurance transaction is underwriting a specific risk at the time of valuation, it is much less flexible but would circumvent the limitations of the Football Regulatory Rules and insulate against insolvency.

\subsection{Beneath a floating charge}

The second method for securing a loan might be to utilise a charge over a designated bank account where, following payment to the club, cash equivalent to the value of the players' economic rights would be deposited. ${ }^{110}$ This could be an equitable assignment of the proceeds as permitted under FA and PL rules. ${ }^{111}$ Although as previously mentioned, it is unclear whether such a transaction falls foul of FIFA TPO restrictions, regardless of FA rules. ${ }^{112}$ The charge over the designated account could be blocked in an attempt to create a fixed charge but it seems most likely that it would be floating due to the cash flow dependency of most clubs. It should be noted this practice has long been used (at least in the UK) for securing lending. ${ }^{113}$ It is for this reason that exploring this method of security is so crucial: precisely because it is common market practice, it is important to examine whether this creates the desired effect and whether they comply with FIFA rules. Understanding how this would function in relation to TPO is easiest if we use our example.

The reader will recall that United bought five players, totalling $£ 350$ million on the transfer market. They approached BB to provide financing for the club. This financing ought not be to fund the purchasing of players specifically due to TPO limitations. BB would provide the capital, instructing United to create a closed, designated account with BB, or another financial institution. BB would then hold two charges, a floating charge over 'the whole or substantially the whole of the company', and a charge over the designated account with a negative pledge limiting United from using the designated account for future security. This preserves BB's security priority in the event of insolvency. An observer may question why a floating charge over the designated account is necessary if $\mathrm{BB}$ would provide a

\footnotetext{
$\overline{110} \operatorname{Re~BCCI}$ (No 8) [1998] AC 214.

111 See Part 3.

112 See Part 4.

113 Ibid.
} 
floating charge over the whole or substantially the whole of the company. The answer to this is twofold. Firstly, it is likely that most of the club's assets are secured. Most clubs are highly geared, and there would be little advantage of the priority BB would receive (in relation to the other secured lenders and the football creditors). Second, the little assets free would be eroded through the insolvency process, a charge over a specific account allows for greater control with less over-head scrutiny.

The value of the floating charge could be valued at a margin BB felt comfortable with and would float over the designated account. One may recall an example above involving Pogba, where BB felt collateral of $£ 360$ million was necessary using conservative valuations. For example, despite the fact that Ronaldo's value fluctuated between 70-110 million, he would only be considered worth $£ 70$ million when calculating the future revenue from his sale. Thus, BB requires a list of players greater than the ones bought with the initial $£ 350 \mathrm{~m}$. Several covenants would be linked to the charge. United would disclose a list of 'specified players' whose current market value, calculated at an agreed time and method would equate to the value of the floating charge. Crucially, to avoid TPO regulations in the Football Regulatory Rules, United would not be restricted in changing the names on that list. Thus, if they subsequently sold Mbappe and purchased $\mathrm{X}$; they would be free to place $\mathrm{X}$ or any other player onto the list—so long as the valuation totalled the specified $£ 360$ million. Undeniably, great effort will be required to determine an accurate valuation, but regardless of how difficult it is, it is possible. United would further covenant that either (1) use the designated account to receive funds deriving from sales of specified players or, (2) that funds equivalent to the value of funds paid from the sales of specified players is transferred into the designated account following a preagreed period of time. The advantage of the scheme is that United may well develop a new player, let's call him Smith. If Smith is sold, for $£ 65$ million on the eve of insolvency, BB can secure against his proceeds because BB's structure of collateral is not linked to a specific player but to the profits (for the club) of the rolling 'stock' of player contracts.

Alternatively, United may agree to equitably assign the future proceeds of the specified players to BB. In either case, the engagement of the charge will need to be fine-tooled enough to allow United to continue operations without breaching the charge or requiring permission to access the funds. It is suggested that a solution to this might be that the requirement to pay into/use the designated would not itself crystallise until the club entered administration was relegated, or upon the notice of BB. This clause may very well expand to include defaults. The importance of such a clause would be to provide United the flexibility to alter the specified player list as operational needs changed, providing the flexibility to use player sale proceeds for business as a going concern unless and until BB felt its recovery was in jeopardy. The engagement of administration could activate the insolvency deprivation rules, and this will be examined in Part 5 below. Relegation, it is suggested, is an event which could result in the need to sell players to cover the traditionally drastic reduction in revenue which results. Whatever the activation clauses for crystallisation, the lender would acquire a charge over liquid assets and not the players' economic rights themselves.

\subsubsection{Article 18ter regulations}

The FA Rules ${ }^{114}$ require written approval prior to completing the transaction. As mentioned above, PL Rule U. $38,{ }^{115}$ the rule limiting third-party investment into players, mirrors FIFA Article 18ter-the aforementioned rule which restricts player rights assignments. U.38.10 allows the selling club to assign its Compensation Fee to a Financial Institution. However, indubitably this is related to a specified transfer. To requote FIFA Article 18ter from above 'compensation payable in relation to the future transfer of a player from one club to another or, is being assigned any rights in relation to a future transfer or transfer compensation' (emphasis added). This seeks to entrap compensation paid or assigned. Transfer compensation is not defined, and it must mean the compensation to discharge the obligation arising from the transfer. Neither of the discussed transactions would be limited by this interpretation. As established in Re BCCI (No 8), ${ }^{116}$ the proceeds of a debt are not the same thing as the compensation used to extinguish the debt. A floating charge over a designated account could not, therefore, capture compensation fees, but instead reference the value of the compensation fee and, through separate contractual arrangements, send proceeds into the account.

Comparatively, FA Rule A. $2^{117}$ operates more comprehensively than PL Rule U.38 and FIFA 18ter. It imposes a prohibition on any payment, direct or indirect, assignment, novation, or transaction of any right or obligation in connection with a transfer [etc.] is comprehensive. It also reinforces the idea that, in having to specify 'indirect' in contrast to 'direct', that the other rules are either impliedly affirming the FA interpretation, or impliedly allowing indirect assignment. This further brings forth questions with regard to the FA and Premier League's implementation of FIFA 18bis and 18ter.

\footnotetext{
114 The Football Association The Complete Handbook 2017-2018, 'Rules of the Association 2017-2018' Adopted 18th May 2017, Part D6-D7, 307.

115 PL Handbook, Rule U.38.

116 Re BCCI (No 8) [1998] AC 214.

117 The Football Association The Complete Handbook 2017-2018, 'Rules of the Association 2017-2018' Adopted 18th May 2017, FA Rule A.2, p. 95.
} 
The FIFA clauses specify that no variation or amendment are authorised, how can it be that there is discretion and further that there are carve-outs?

In view of these discrepancies, however, it may be possible to develop a cohesive view of the Football Regulatory Rules. Clearly the carve-outs are authorised for a reason and whilst one may be tempted to use the more lenient of rulesthe FIFA rules, at least procedurally, remain supreme. With that said, on our proposed interpretation of Article 18ter, it still remains possible to use player economic rights as security albeit in a contrived manner.

If not for the mirrored exceptions in the PL and FA rules, FA Rule A.2 would not allow any form of security-taking with regard to player economic rights. The FIFA Article 18ter is not constructed as favourably as A.2 with regard to limiting transactions which are unfavourable and permitting those which are desired. 18ter is susceptible to loopholes which A.2 (and its corresponding carve-outs in Regulation B) are simply not. ${ }^{118}$ B.1.8 and B.1.9 allows for clubs to assign its compensation fees to Financial institutions. ${ }^{119}$ This carve-out is wide enough to allow a security charge over a designated account, and possibly direct assignment, to remain valid. As previously highlighted, an ABS would transfer the interest to a third party which is not a financial institution and would thus not fall within the FA's carve-out. Still, the endeavour has been to create a transaction which could be argued to be valid in view of all Football Regulatory Rules deriving from both FIFA and the FA.

\subsubsection{Article 18 bis regulations}

The stricter rules of FIFA Article 18bis and the related clauses within the FA and PL rules would not affect a floating charge over a designated account, as the transaction does not affect on-pitch decisions. The FA rules set out in 'ThirdParty Interest in Players Regulations 2017-2018, specifically the aforementioned A.1 and Preamble provide clarity that a party "holding an interest in the registration, federative, economic or similar rights of a player may, as a consequence of that interest,' have the ability to influence the manner in which the club operates. However, a floating charge would be unlikely to procure this effect to the same substantive risk as a synthetic ABS. BB would be unable to, in such circumstances, induce (or crucially) 'influence materially' the club or its players because it would not own any rights in any players.

The structure of the transaction is such that the lender has an interest in the proceeds of club selected transfers which neither engage at the discretion of BB, nor are they capable of being influenced. B neither has any 'material influence'

\footnotetext{
118 Ibid, Regulation Rule B, p. 100.

119 Ibid.
}

nor any interest of a player. BB holds an interest, at most, in the club's compensation right. Applying Re Spectrum $P l u s,{ }^{120}$ the distinct nature of compensation rights and the realised proceeds of those rights is a thin meniscus, but one of crucial differentiation. The proceeds are deriving from, but crucially not an interest in, right of a player. The transaction does not create third-party ownership insofar as the lender never owns (or in law, most importantly possesses/ holds proprietary right over) the players' economic rights. Moreover, the nature of the floating charge would mean that an interest in the asset beneath the charge would not develop a corresponding interest until crystallisation. Romer $\mathrm{LJ}$, in Illingworth $v$ Houldsworth, held that a crystallised floating charge, did not affect the assets themselves, stating that:

[A] floating charge is ambulatory and shifting in nature, hovering over and so to speak floating with the property which it is intended to affect until some event occurs or some act is done which to cause it to settle and fasten on the subject of the charge within its reach and grasp. ${ }^{121}$

The differentiation is crucial for two reasons:

First, the proposed transaction is referenceable to the rights of a player but is not themselves the rights. At no point could the transaction result in the lender acquiring the actual rights of a player.

Second, a fixed charge requires the permission of the lender before any action is taken by the debtor in relation to the asset which the fixed charge applies. In Spectrum Plus, ${ }^{122}$ the House of Lords highlighted the capacity for a company to deal with assets which rests beneath a floating charge. Thus, Spectrum Plus provides uncertainty as to the circumstances where a charge over the account would amount to a fixed or floating charge, but this would be a matter of construction. With that said, a floating charge, whilst susceptible to the proscribed part, provides a strategic advantage. Readers will recall that under English jurisdiction, the Enterprise Act 2002 resulted in a proportion of the floating charge being earmarked for unsecured creditors, this was dubbed 'the proscribed part' and apportioned part of a floating charge holder's portion of the insolvency dividend. ${ }^{123}$ Extensive criticism has been fielded against the proscribed part, and the floating charge generally. ${ }^{124}$ The floating charge enables the club the ability to use the designated account as a general player transfer account, enabling the lender security over the entire potential income from any of the club's player revenues. Thus is ought to be clear that collateral of

\footnotetext{
$\overline{120}$ Re Spectrum Plus Ltd (In Liquidation) [2005] 2 AC 680.

121 Illingworth $v$ Houldsworth [1904] AC 355, 358.

122 Re Spectrum Plus Ltd (In Liquidation) [2005] 2 AC 680.

123 Enterprise Act 2002.

124 See for example Mokal (2005).
} 
player value must not be over any specific player value but over the revenue of player transfers generally. ${ }^{125}$ Alternatively, a lender might attempt to secure the entire club by first debenture over all the club's assets-however the risk of this would be that it would be likely too unsophisticated of a trigger to pre-empt insolvency, and therefore the unlocked value in player contracts would be lost. ${ }^{126} \mathrm{We}$ might remind the readers that the objective here is to examine the risks and techniques a lender might use to securitise player economic values - an endeavour done in light of real-world attempts to do so. The relatively paltry sanctions handed to clubs by FIFA only exasperate the need to ensure lenders are actually gaining security - to interrogate the real-world practice.

The floating charge would engage the FA and PL rules within A. 2 but would be exempt if the lender were a financial institution and qualified for the FA exemptions. Under the proposed interpretation of FIFA 18ter, a charge of this kind would strictly speaking not be an interest in the compensation of $a$ (specified, singular) player. ${ }^{127}$ Moreover, a designated account would be necessary as a fixed charge onto player economic values would explicitly violate FIFA regulatory rules and likely FA regulations because it would mean a defaulting event would allow the lender to force the sale of the player, influencing club policies, and would take direct control of the player. Any form of charge over a designated account seems unlikely to violate FIFA rules. Within England, only the interpretation of FIFA rules ought to induce caution for lenders when seeking player's economic value as collateral. Both proposed transactions, a floating charge and the ABS seem to be the gold plating necessary to avoid FIFA sanction and ensure proper enforcement (as will be seen below) neither the FA nor the PL rules affect collateral taking in the ways envisaged above.

A second possibility might be to have the club itself place a charge over the players' economic rights (a charge over a contingent receivable) which, in order to discharge the obligation is conditional on the players' rights proceeds placed into the designated account. ${ }^{128}$ It is uncertain whether this

\footnotetext{
125 Thus, avoiding the risk of a marquee player refusing to transfer elsewhere and thus resulting in the potential capital becoming illiquid. A effective example might be of PSG, whose bench depth is so substantial, it would matter little which players were sold, so long as the aggregate sold value sufficiently covered the debt.

${ }^{126}$ It might be further noted that a debenture is any type of charge over an asset.

127 See above 'Article 18ter regulations'.

${ }^{128}$ Functionally this seems similar to the concept explored in $R e$ Charge Card Services Ltd [1987] 1 Ch 50, and as anticipated in Halesowen Presswork \& Assemblies Ltd $v$ Westminster Bank Ltd [1971] 1 QB 1, 46, approved in National Westminster Bank Ltd v Halesowen Presswork [1972] AC 785, 802 (Viscount Dilhorne): 'no man can have a lien on his own property ...I cannot myself understand how it could be said with any kind of accuracy that the bank had a lien upon its own indebtedness to the company.'.
}

would be conceptually possible as the ownership right would include the lesser equitable charge. Although the fusion of equitable and legal title creates conceptual difficulty in placing a charge of one's own asset, the possibility has nevertheless been left open. ${ }^{129}$ It may also be possible to construct a negative covenant, so that the club exercises its ownership rights $a$ s if such a charge existed, making the proceeds a flawed asset, subject to the insolvency limitations such as the Anti-deprivation and Pari Passu principles. ${ }^{130}$

Why go through such constraints to ensure the proceeds of the players' economic rights reach a designated account which is itself subject to a security charge? The limitations of FIFA rules are extremely restrictive and their effect on insolvency (as seen in Part 5) means that designing ways to ensure the opportunity of enforcement exists. A negative charge would mean that the proceeds were a flawed asset which could only provide the club the assets where the lender (and charge holder over the designated account) would be entitled to enforce. The mechanism would result in not designating the players' economic rights to a nonfootball-related party whilst ensuring that the proceeds are to appear where they ought to: in the designated account.

\section{Securitisation consequences}

Two key discussion points are driven within this section. Having traced the regulatory rules within association football and subsequently constructed agreements which would be satisfactory to fall within the assignment carve-outs set out in FA/PL rules (and in being confident that it would not activate FIFA regulations), it is now our attempt to investigate whether the proposed collateralisations are effective as security. Principally, does it shield the collateral taker from insolvency related risks and secondly does it provide any benefit through the Financial Collateral Arrangement Regulation (No 2) 2003 ('FCAR') collateralisation requirements? These two requirements are central to the utility of security in the mind of a commercial lender as they mitigate the exposure the lender has against the borrower's credit risk. If PEV can be said to provide enforcement or some form of security-like protection within insolvency, then the lender has shifted their risk of lending from the borrower's credit risk to the credit risk of the asset itself. Before examining the first of these two points, it should be noted that the previous section examined the effectiveness of both

\footnotetext{
$\overline{129} \operatorname{Re~BCCI}$ (No 8) [1998] AC 214.

130 British Eagle International Airlines Ltd v Compagnie Nationale Air France [1975] 1 WLR 758; Belmont Park Investments Pty Ltd v BNY Corporate Trustee Services Ltd [2011] UKSC 38; [2012] 1 AC 383.
} 
collateral-taking techniques with regard to enforcement. Both are limited in their nature due to the third-party ownership restrictions which limit non-football entity lenders from taking actual possession of PEV, ${ }^{131}$ an outcome with several consequences. Primarily: the lack of ability to possession will have consequences for certain exemptions which may be beneficial to a lender which is set out within the FCAR regime. Additionally, as will become clear, the restrictions on enforcement set out in Part 6 means that security over a PEV in the form of a charge may mean a lenders security becomes valueless upon winding-up. The reader will recall that we have previously proposed a solution by appointing an out-of-court administrator.

\subsection{Treatment within insolvency}

It is clear that taking players' economic rights as collateral will require a scheme to convert the value from its present form into an asset which can be securitised. Clearly, equitable assignment is possible within the FA's provisions but is incongruent with FIFA regulations. Proposed security will either take the forum of a floating charge with overlocking covenants or as an asset-backed security. The former ought to be explored further in order to understand the potential consequences insolvency might have on the security. Sport, perhaps because of the cash flow heavy nature, has been noted by the courts as being particularly susceptible to insolvencies. ${ }^{132}$ What is particularly relevant is the level of pro rata dividend non-football-related parties within insolvencies receive. Richards J's judgment in Football Creditors, evidences the implications of a club going insolvent. Richards J cites Crystal Palace FC's 2010 winding-up and Plymouth Argyle FC's administration to highlight the full compensation 'football creditors' receive, disproportionate to non-football-related parties receiving 'a dividend of less than $2 p$ in the pound'. ${ }^{133}$ These paltry dividends highlight the importance, perhaps necessity, for lenders to collateralise lending agreements. Richards J held that insolvency rules were not offended by Article 4.5 of the Football Leagues articles of association, which authorised the league to force a sale of the club's FL membership share ('golden share') effectively preventing the club from the right to compete within the league, severing employment contracts, and prioritising creditors within the football world. The clause activated upon any insolvency event. The consequence of this would be the club not being ranked within the league ladder and therefore missing out on the annual earnings resulting from television and media contracts made between

\footnotetext{
131 Seen in Part 3 above.

132 Football Creditors Case [2012] Bus LR 1539.

133 Ibid, [8].
}

the league and third parties. In Football Creditors, HMRC had argued that Article 4.5 ought to fall to the deprivation clauses within insolvency as it deprived the club of its media revenues and value in player registration rights.

At paragraphs 117 through 119, Richards J outlines the significance of the 'golden share' on a club, principally the 'three principal rights' it affords. First, the right to participate in league competitions, 'generate revenue from gate receipts advertising, exploitation of its name and brand, player sales and other commercial activities'. ${ }^{134}$ Second, access and payment from the 'pool account' a centralised account collecting revenue from media, primarily television revenues. It was this point that was most extensively litigated. Lastly, a club is:

entitled to have players registered with them, and during their contract period the players are normally the clubs' most valuable assets. Under regulation 61 of the FL regulations, all registrations of players with a club terminate if it ceases to be a member of the FL and the registrations vest in the FL. The club thereby loses any possibility of selling its players. ${ }^{135}$

However, Richards J was unconvinced by HMRC's emphasis that loss of player registration was a loss of value. He believed that if a club entered liquidation, it would cease business and therefore the employment contracts would terminate 'irrespective of the termination of their registration'. In Administration, where a club does not cease business, Richards J believed the registrations were not lost. Two things ought to be said on this. First, preservation of registrations within administration is vital for a third-party lender, however, problematically any lender seeking to enforce the use PV as collateral will be estopped by the administration moratorium. As a security, therefore, the value might be lost. Further, it seems likely that either the administrator or a court could use the powers inherent in Schedule B1 para 70 , to use the funds captured by the book debt floating charge to aid the club in trading out. ${ }^{136}$ Therefore, the value is essentially entrapped upon entering insolvency and any enforcement mechanism, such an agreement to sell players on default, would clearly fall within the FIFA rules designed to prevent influencing on-pitch decision-making. If the lender can construct the floating charge agreement so it would fall within the FCAR, then the power of disposal of charged property would be disapplied. ${ }^{137}$

Later in his judgment, Richards J outlines why, despite Article 4.5 specifying that entering administration is grounds

\footnotetext{
$\overline{134}$ Ibid, [117].

135 Ibid, [118].

136 Insolvency Act 1986, Sched. B1, Para. 70 and 71.

137 Benjamin (2007) p. 389; Regulation 8(3)(b).
} 
for withdrawal of the 'golden share', a club 'could enter administration' ${ }^{138}$ and complete the current season effectively trading out. The 'golden share' transfer would be suspended until entering liquidation. ${ }^{139} \mathrm{He}$ reasons that, as with Article 80 (which applies to clubs defaulting in making payment towards football creditors), the removal of the golden share would not 'deprive the club of any existing right' as if it failed to complete the season by entering insolvency, Richard J continued and made clear that the employment contracts would dissolve upon liquidation. ${ }^{140}$ In his reasoning, he stated that administration did activate the request to transfer the golden share. Such a request would not be executed until liquidation when the club could no longer continue the season. Although Richards J did not rule on whether the economic rights would dissolve upon the dissolution of the employment contracts, it is supposed, that a player's economic rights would be valueless inside liquidation since they are derivative of the employment contract themselves and the registration rights would revert to the FA because the player's underlying registration with the league would not be affected by the dissolution of the club. It must be reiterated here clearly that there is a difference between registration rights and the employment contract. The registration rights vest in the club (and form part of the players' transfer value) but would not disappear following the dissolution of the employment contract whereas the economic rights derive from and dependent on the existence of an employment contract (readers will recall a transfer value is calculated often in part by the remaining contractual length of the employment contract).

If players' economic right dissolves upon liquidation, it stands to be determined whether the player would become a so-called free agent, or whether the FA would sell the player on the transfer market. If it is the latter, do the lender's right in the PEV remain? This is especially relevant where a traditional assignment of rights (as authorised under the FA rules) occurs. We suggest that within the proposed schemes above that PEV would not survive as they derive from the employment contract between the club and the player. However, if those contractual relationships were to be transferred out of the club to the league, then, should the league have constructed knowledge of an equitable assignment (which it would by way of being provided notice by the club at the time of the transaction) then the interest in the players economic rights must remain.

At this juncture, it is useful to consider the relationship between English insolvency rules and the legal rules of a league. Once again it is useful to consult Football Creditors

\footnotetext{
138 Football Creditors Case [2012] Bus LR 1539,[141].

139 Ibid, [114].

140 Ibid.
}

as Richards J's finely tuned analysis indicates the approach courts are likely to take when interpreting the legal rules of a league within the parameters of insolvency. The first insight that can be gleaned from Richards J's judgment, is the quoted evidence provided to the court regarding the general steps taken by clubs in attempting to rescue themselves:

100.1 The League issues a notice to OldCo (the company that owns the member club, and holds the share in, or membership of, the League), requiring it to surrender up that membership [... suspending] the withdrawal of membership to give the administrators of OldCo time to try to sort out OldCo's financial affairs. 100.2 The administrators keep the club trading during this process by one of two means:

100.2.1 They sell assets of the club (principally, player registrations) to raise funds to pay operating costs in the interim. A good example of this would be the recent case of Crystal Palace FC where the administrator used player sale proceeds to help fund the administration (emphasis added); and/or

100.2.2 A prospective purchaser advances funds on a loan basis, as happened in the case of Wimbledon FC, with those sums either reducing the purchase price if and when a sale to that purchaser is completed, or else they are paid as an expense of the administration if a sale to a third party is completed. Another example is the administration of Luton Town Football Club, where a consortium of local businessmen (under the banner Luton 2020) provided non-recourse, first priority funding for the club, their aim then being to keep the club going while they tried to complete its purchase.

100.3 [...] Based on new funding coming into OldCO [the administrators propose a CVA] or a sale of the playing assets of the club to NewCo. As part of the transaction, the football creditors have to be paid or provided for in full. ${ }^{141}$

100.5 Where no transfer is proposed, [...] OldCo emerges solvent from administration (usually by means of a CVA), [... and] retains its membership, [...the League] exercises [...] discretion to cancel the formal notice to withdraw the share from OldCo, subject to the various conditions [...]. This will include a provision that the debts owed to football creditors $[\ldots]$ are met in full.

100.6 [...] more usually OldCo sells its assets to NewCo, applying the consideration to satisfy its obligations to its creditors under the CVA. [...] If the

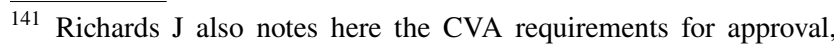
including $75 \%$ approval. 
League is satisfied, it cancels the formal notice to withdraw the share from OldCo by exercise [...] discretion, and consents to the transfer of the share from OldCo to NewCo. [...]

As seen, this is a staged process; the first stage involving administration, and at 100.2.1 it is observed that the sale of players occurs to raise funds. It would be at that point that the agreement between the collateral taker and the club would engage. As with the flawed assets in Belmont, it could be argued that the proceeds of the player sales were bound to be earmarked for the designated account, however, this argument would acknowledge that the transaction was a sham designed to circumvent FIFA Football Regulatory Rules. In Doyen v Sporting, heard before the Swiss constitutional court, a TPO contract was held valid, despite violating FIFA rules. ${ }^{142}$ It is unclear how the English court would characterise the transaction in light of the legal substance of the proposed floating charge contract being (legally) possible within domestic English law but not FIFA rules, but the Swiss court does provide an interesting indication that the contract would be valid. Doyen has affirmed that courts have upheld the validity of contracts under domestic law which vest legal rights which derive from player contracts, despite the fact that the practice is sanctioned under Football Regulatory Rules. The judgment is particularly useful for a potential lender, vindicating that the validity of their collateral does have legal standing, but it might be noted that it lacks a crucial point unique to English law: the law of equity, which has always notoriously operated to unwind transactions designed to circumvent rules. As we note, the threat at English law is not whether the contract is valid but whether the courts would void the contract for a lack of capacity or for inducing a breach of contract. These questions operate outside of, but also within, the question of whether a lender would have an enforceable security inside insolvency.

Whilst the collateral taker would not be able to enforce their security due to the administration moratorium, an administrator would have to apply to the court in order to use the charged assets to achieve the objective of the administration. ${ }^{143}$ What is clear from the judgment in Football Creditors is that club's relationship with the league (and with FIFA regulations more generally) is crucial to navigating and understanding for a lender. A security priority will be vital to avoiding the unfavourable position of ranking behind football creditors.

\footnotetext{
142 Oskar Van Moran, Doyen vs. Sporting II: The Bitter End of Sporting's Fight at the Swiss Federal Supreme Court, 20th February 2017, http://www.asser.nl/SportsLaw/Blog/post/doyen-vs-sporting-iithe-bitter-end-of-sporting-s-fight-at-the-swiss-federal-supreme-court -by-shervine-nafissi (accessed 20th November 2018).

143 Insolvency Act 1986, para 3.1, Sch B1.
}

It is also clear that the league holds the power to extract players out of the collapsed club and into the possession of the league itself. If insolvency accelerates quickly and the club enters into liquidation, then the lender's collateral will be dissolved, undoing the entire intention of the agreement. It must then be necessary for the security clamp to operate quickly. A derivative or floating charge would achieve this, albeit in different ways. A floating charge over the whole or substantially the whole of the company, in addition to the security of the player will thus be necessary for the lender to qualify as a floating charge holder and, should relegation operate as an event of default, facilitate the lender appointing the administrator. As there is no requirement for a business to be near or within insolvency for an out-of-court administrator to be appointed the lender could trigger appointment of an administrator All that is necessary is for the floating charge to be drafted in such a way that club relegation is sufficient grounds for an event of default or appointment of an administrator. Doing so would require the lender to prove that the club would 'likely' become insolvent, based on the drastic reduction in revenue resulting from relegation, a lender would be able to make a strong case that relegation operates as a strong indicator that future revenues decline substantially (that current marquee players may be better suited elsewhere) and that the club's current financial position is untenable. ${ }^{144}$ Selling players would also mean that the club would have sufficient funds to trade out of administration without cannibalising the earmarked funds. In other words, it may be best for the lender to enforce their debt against the realised revenues (of the club) resulting from player transfers. It would be highly likely that an administrator, even one not appointed by the lender, would sell these players in order to pay off creditor debts in an attempt to trade the company out of administration. Thereby the sale would thus trigger the sale of the designated players and entrapping the revenue into the lender's charge. Neither the designed player nor the purchasing club would necessarily be aware of the arrangement because the lender's charge is over a club's account-not the player contract.

Secondly, as previously explored a derivative could be used to securitise a lenders debt. In order to be effective, Football Creditors indicates the derivative must insured against either an insolvency event, an event triggering the transfer of player value to the league, or against terminated contract following an insolvency-related event. This would

\footnotetext{
${ }_{144}$ See paragraph 15, 16, \& 17 Schedule B1, Insolvency Act 1986; argument that the charge is unenforceable or invalid because all the company's assets are in fact subject to fixed rather than floating charges under the relevant debenture, or were previously charged to another lender, is unlikely to succeed see, Saw (SW) 2010 Ltd v Wilson, O'Keefe and Gray (as joint administrators of property edge lettings ltd) [2017] EWCA Civ 1001. Also see rule 3.17 of the IR 2016.
} 
transfer the insolvency risk to the insurer and protect the lender. This is additionally advantageous in that it is referable to, but not dependent on, the player's actual registration and economic rights because it is an insurance contract, similar to a CAT bond and would isolate the risk of player value dissolving upon the collapse of the club and subsequent termination of employment contracts because the insurance derivative would kick in and offset the resulting loss.

\subsection{Security enforcement}

Designed to reduce systemic risk, the FCAR collateralisation requirements have unfortunately been difficult to apply. Several cases have struggled to identify when the FCAR arrangement arises, even within financial transactions between sophisticated parties. ${ }^{145}$ These issues are worth mentioning here because, in tandem with the discussion above relating to English insolvency rules, it would seem necessary that a transaction using player economic value as collateral would fall into the FCAR in order to be effective in enforcement and provide adequate certainty to the lender of his rights.

Several key advantages exist if the FCAR is engaged, notably with regard to the floating charge over book debt arrangement. Such a charge need not be registered, it is not caught by a stay, there is a right to appropriation, a right to use collateral, priority over expenses, and stay on further set-offs. However, a Floating charge will not fall within FCAR unless the only rights the collateral provider has are substitution and withdrawal of excess collateral. It would require that the charge crystallise before insolvency. Thus, there is a lack of clarity as to the application of an FCAR in relation to a floating charge.

The FCAR requires that parties in the transaction are nonnatural persons and collateral provided must be 'financial collateral', ${ }^{146}$ which is 'is delivered, transferred, held, registered, or otherwise designated so as to be in the possession or under the control of the Collateral Taker'. ${ }^{147}$ It allows the collateral provider to substitute equivalent Financial collateral or withdraw excess. ${ }^{148}$ Regulation 3 sets out a security interest, which must be a 'relevant financial obligations', which is a present or future, actual or contingent or prospective obligations. ${ }^{149}$ The obligation may arise in equity or in law, and includes a floating charge. ${ }^{150}$

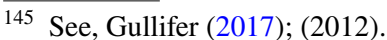

146 FCAR (No 2) (2013); Gray v GTP Group Ltd [2010] EWHC 1772 (Ch).

${ }^{147}$ Re Lehman Brothers International (Europe) [2015] EWCA.

148 EUECJ C-156/15Private Equity Insurance Group SIA v Swedbank AS [2016]; Gray v GTP Group Ltd [2010] EWHC 1772 (Ch).

149 FCAR (No 2) (2013) Regulation 3; Part 1 para 3.

${ }^{150}$ Ibid.
}

Applying our United example to these regulations, we find that we would have an arrangement in writing, where the purpose is to secure a financial obligation. In our case it is a present, actual obligation owed to the collateral taker (BB) by the Provider (United). United has correctly created a security interest in the proceeds of the sale of any of the United players, which is equitable. This is through a floating charge. What lies in question is whether the collateral is 'in the possession or under the control of the collateral taker' The lender, BB, could be in possession or control of the book debt once the realisation of player economic rights has occurred, but it is doubtful that BB would be in either prior to the sale of the player. Meaning the FCAR would engage after the player is sold but this would have to occur before United entered administration or insolvency. The enactment would thus be an exceptionally narrow point. The right for substitution and withdrawal would be consistent with the limitations set out in the above-exampled agreement and in an agreement which one might conceive to be secured over players' economic rights. Those rights could be substituted with other, equivalently valued rights. However, the example is not without issues. FCAR rules have been inconsistently applied and the precise meanings of legal phrases within the regulation remain ill-defined by the courts. The consequence is that there is little certainty as to whether a floating charge, as conceived, would be adequately protected by the regulation. This leaves a lender's legal rights in a precariously ill-defined position.

\subsection{United example returns}

A great deal has been learned through the framework of the United example set out at the fore of this paper. It has been shown that substantial regulatory hurdles exist, and a lack of clarity regarding the hierarchy of TPO rules has brought forth a gap in Football Regulatory Rules and their enforcement. If we recall the example, we might now see that BB could secure the debt to United under certain, rather large caveats. If United's other assets (save its players) are already subject to a charge, then it might secure the future proceeds of the sale of a varying list of players using the collateral instruments set out in Part 5 (e.g. floating charge, ABS, etc.) This way, it is the club's discretion which player to sell, when, and to whom. ${ }^{151}$ This accounts for the peculiarities of real-life: the desires of players to go to certain clubs, the fluctuating market values of individual players as their contracts decline and playing forum changes. At no point does BB influence or 'force' another club to sign, the underlying player transfers between clubs occurs entirely independent from $\mathrm{BB}$ - the buying club and the player might

$\overline{151}$ Thus, avoiding TPO rules. 
not even be aware that BB will receive the proceeds. No consent is needed from the player because the economic rights which BB would be so entitled are derivative rights from the employment contract for United's benefit. For example, if United sold Ronaldo in the above example, Ronaldo might be entirely unaware that United has assigned their proceeds from the economic rights because they are entirely irrelevant to him or his legal rights. It would be the equivalent of borrowing a friend's umbrella after he bought it from the store-the store need not know whether there is a subassignment of the umbrella only that its relationship with the friend was valid and executed. BB's only concerns then are the very substantial ones relating to Football Regulatory Rules and ensuring that the rights are sufficient to produce enforceability upon insolvency.

\section{Consequences and conclusion}

Football Creditors provides a strong indication of the courts willingness to observe the private Football Regulatory Rules so long as they do not violate English law. We submit that a court would be unlikely to allow a transaction which, while compliant with English law after re-characterisation ${ }^{152}$ with no substantial loss to the lender-brazenly induces the club to violate its agreements with FIFA, and the FA. At the least it might be argued that upon constructed knowledge the lender knows that FIFA regulations ban such transactions (irrespective of whether the FA allows it) and that the club lacked the capacity to enter into such a contract. At most, as was briefly forwarded, contracting in breach of private international law ought to be understood as analogous to either inducing breach of contract or seeking enforcement of a judgment which would cause one party to commit an offence. ${ }^{153}$ As a matter of comity the English courts do not enforce such contracts. If a lender is seeking to enter into an agreement with a club in order to utilise a players' economic rights as security for a lending agreement, it must be sure that the construction of the transaction sufficiently avoids violating the Football Regulatory Rules. It will further be necessary for the transaction to be within the FCAR in order to avoid issues with enforcement upon insolvency.

It is clear that FIFA rules are more restrictive than FA rules with regard to players' economic rights as security collateral. The inconsistency between the FIFA and FA rules is particularly noticeable where FIFA rules are said to apply to the national level but have direct effect onto clubs. The result is muddied clarity with regard the extent to which clubs are

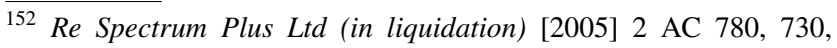
735-6 (Lord Walker).

${ }^{153}$ Regazzoni v K.C. Sethia (1944) Ltd [1958] AC 301. able to unlock the value stored in players' economic rights. It also begs the question: Is the practice to have the exemptions seen in FA rules or are the FIFA regulations to be read strictly? As we have seen, FA rules permit assignment to Financial Institutions whilst FIFA rules do not. Perhaps, examining other national association rules will provide clarity, although the comparative analysis of said rules is best left for another paper. It was also noted that the prevalence of the practice of taking players' economic rights as security, in light of the inconsistency, highlights the relevance of understanding whether the practice was able to produce an effect where the security was perfected. Applying Roy Goode's six criteria for perfected security, it is clear that issues of enforcement, beneficial ownership, and priority are substantial, and are issues which can be attributable to the nature of the asset: something derived from an asset which draws its legal rights from an employment contract. In many ways, as seen in Part 3, we have observed that the asset is dependent on the acceptance of FIFA and the FA who apply the Football Regulatory Rules set out in Parts 2 and 3. The dependency on FIFA creates a legal right which is exceptionally fragile. The contradictory nature of those rules only deepens these issues.

Having understood the inconsistency of rules, the paper then undertook the endeavour to propose a few transactions which might allow a secured creditor to take collateral in a players' economic right. What was clear was that FIFA rules must be circumvented if enforcement is to be desired. The two proposed transactions might circumvent these rules to allow a lender to enforce against player economic rights when used as collateral. However, in insolvency, the PERs are evermore fragile. In administration they retain value but cannot be enforced due to the moratorium set out by the Insolvency Act. ${ }^{154}$ There is a caveat, a silver lining in which a lender may be able to enforce. The rules on moratoriums may be circumvented if the transaction can be shown to fall within the Financial Collateral Directive. By contrast, in winding-up liquidation, the PERs become immediately valueless and cannot be enforced. The effectiveness of PER as collateral is thus severely limited by the risk of insolvency. Using a players' economic rights may provide security up until the conclusion of administration, but in the situation of an immediate and sudden insolvency, the creditor would have little advantage over other non-football creditors and, as seen in the case of Football Creditors would be left with little by way of dividend. This is the direct result of the conflict in FIFA/FA/PL rules. If FIFA rules are seen to prevail, then lenders should express severe caution when using PER to collateralise lending, regardless of what FA rules allow. The authors suggest that the FIFA rules apply with direct

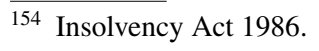


effect, but that they are clearly inconsistent in their application, reflective of a regulatory regime which is failing to effectively enforce rules (akin to the Regulation on Working with Intermediaries).

It has been the objective of this paper to explore the precarious use of players' economic rights as collateral security for creditor lending activities. It is a technique which is increasingly common in practice. With clubs increasingly relying on the transfer market to generate revenue, retention of players holds much of the potential value in an operating club. The increasing levels of securitisation of stadiums and future entertainment agreements mean that lenders are frequently looking to other assets to securitise. Some have begun to rely on players' economic rights. It is suggested that without additional collateral or personal guarantees, this is an activity which is extremely dangerous. Lenders are entering into agreements which are not reflecting the riskadjusting results that the collateral actually reflects. This is extremely important to lenders because it directly relates to their collateralisation obligations and their appetite for risk. Many may well believe they are adequately secured, but as seen, that security may well be a falsity. Instead, bearing high risk without an enforcement method and with an inaccurate assessment of the risk-weighted transactions. As clubs increasingly turn to financing to remain competitive, the use of PER to collateralise debt evidences a growing spectre for both lender and borrower. Clubs conduct these transactions brazenly in the face of explicit directives to the contrary, whereas lenders are led to believe they are provided greater safety than actually exists.

Acknowledgments The authors would like to thank Professors Louise Gullifer QC, Richard Salter QC, Kristin van Zweiten, \& Gabriel Moss QC from the University of Oxford. All errors are the authors own.

Open Access This article is distributed under the terms of the Creative Commons Attribution 4.0 International License (http://creativeco mmons.org/licenses/by/4.0/), which permits unrestricted use, distribution, and reproduction in any medium, provided you give appropriate credit to the original author(s) and the source, provide a link to the Creative Commons license, and indicate if changes were made.

\section{References}

Ali P, Robbe J (2004) Synthetic, insurance and hedge fund securitisations. Thomson, London

Benjamin J (2007) Financial law. Oxford University Press, Thomson

Berg T, Steffen S (2015) The total cost of corporate borrowing in the loan market. J Finance 71:1357

Burns T (2007) Structured finance and football clubs: an interim assessment of the use of securitisation. Entertain Sports Law J 4:3
Colomo P (2005) The application of the EC treaty rules to sport: the approach of the european court of first instance in the Meca Medina and Piau case. Entertain Sports Law J 3:1

Davies G (2007) Using intermediated securities as collateral: equitable interests with inequitable results. J Int Bank Financ Law 22:70

Dobson S, Goddard J (2001) The economics of football. Cambridge University Press, Cambridge

Duval A et al (2016) Debating FIFA's TPO ban: ASSER International Sports Law Blog symposium. Int Sports Law J 15:233

Geey D (2009) Third party player ownership: the regulations for premier league and football league clubs or the 2009/10 season. Entertain Sports Law J 7:6

Gullifer L (2012) What should we do about financial collateral. Curr Legal Probl 65:377

Gullifer L (2017) Legal problems of credit and security, 6th edn. Sweet and Maxwell, London

Jones M et al (2017) Clerk and Lindsell on torts, 22nd edn. Sweet \& Maxwell, London

Keohane R, Martin L (1995) The promise of institutionalist theory. Int Secur 22:39

Krasner S (1982) Structural causes and regime consequences: regimes as intervening variables. Int Org 36:185

Maciel M (2016) CAS: effectiveness of CAS awards in the FIFA regime. Legal Issues J 4:21

Magee J (2006) When is a contract more than a contract? Professional football contracts and the pendulum of power. Entertain Sports Law J 4:4

McArdle D (2000) One hundred years of servitude: contractual conflict in professional football before the Bosman ruling. Web Journal of Current Legal Issuesin association with Blackstone Press Ltd. 1 Web JCLI

McFarlane B (2016) Intermediated securities: taking stock. Butterworths J Int Bank Financ Law 31:359

Mitten M (2014) The court of arbitration for sport and its global jurisprudence: international legal pluralism in a world without national boundaries. Ohio State J Dispute Resol 30:1

Mokal R (2005) Corporate insolvency law: theory and application. Oxford University Press, Oxford

Muller O et al (2017) Beyond crowd judgments: data-driven estimation of market value in association football. Eur J Oper Res 263:611

Rawlings P (2012) Avoiding the obligation to lend. J Bus Law 2:89

Rossi G, Semens A, Brocard JF (2016) Sports agents and labour markets: evidence from world football. Routledge, London, p 157

Simpson A (1991) The origins of futures trading in the Liverpool Cotton Market. In: Cane, Stapleton (eds) Essays for Patrick Atiyah. Claredon Press, Oxford

Swanepoel M, Swanepoel J (2016) The Correlation between player valuation and the bargaining position of clubs in the English Premier league. Int J Econ Finance Stud 8:210

Wolff (2005) Assignment agreements under English law: lost between contract and property law? J Bus Law 473:485-487

Publisher's Note Springer Nature remains neutral with regard to jurisdictional claims in published maps and institutional affiliations. 